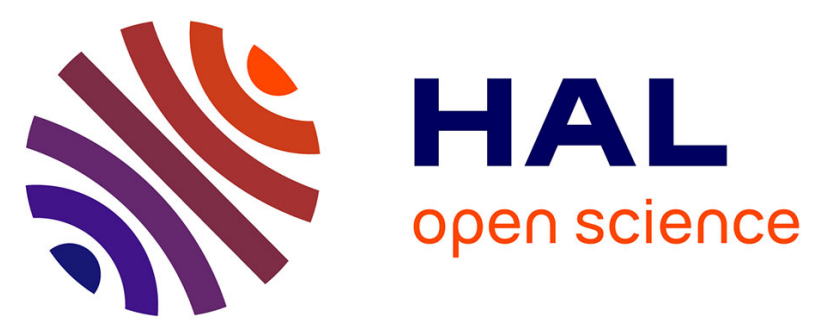

\title{
The persistent Müllerian duct syndrome: an update based upon a personal experience of 157 cases
} Jean-Yves Picard, Richard L. Cate, Chrystèle Racine, Nathalie Josso

\section{To cite this version:}

Jean-Yves Picard, Richard L. Cate, Chrystèle Racine, Nathalie Josso. The persistent Müllerian duct syndrome: an update based upon a personal experience of 157 cases. Reproduction, Fertility and Development, 2019, 31 (7), pp.1240-1245. 10.1071/RD17501 . hal-02472552

\section{HAL Id: hal-02472552 https://hal.sorbonne-universite.fr/hal-02472552}

Submitted on 10 Feb 2020

HAL is a multi-disciplinary open access archive for the deposit and dissemination of scientific research documents, whether they are published or not. The documents may come from teaching and research institutions in France or abroad, or from public or private research centers.
L'archive ouverte pluridisciplinaire HAL, est destinée au dépôt et à la diffusion de documents scientifiques de niveau recherche, publiés ou non, émanant des établissements d'enseignement et de recherche français ou étrangers, des laboratoires publics ou privés. 
The persistent Müllerian duct syndrome : an update

\title{
based upon a personal experience of 157 cases
}

\author{
Jean-Yves Picard ${ }^{a}$, Richard L Cate ${ }^{b}$, Chrystèle Racine ${ }^{a}$, Nathalie Josso $^{a}$
}

\begin{abstract}
aUniversité Paris Diderot, Sorbonne Paris Cité, F-75013 Paris, France; Institut National de la Santé et de la Recherche Médicale Unité 1133, Physiologie de l'Axe Gonadotrope, F-75013 Paris, France; Centre National de la Recherche Scientifique, Unité Mixte de Recherche 8251, Biologie Fonctionnelle et Adaptative, F-75013 Paris, France

${ }^{b}$ Department of Chemistry, Boston University, Boston, Massachusetts 02215 C
\end{abstract}

\author{
Correspondence \\ Jean-Yves Picard \\ Inserm U1133 BFA \\ 5 rue M.A. Lagroua Weill-Hallé \\ Case postale 7007 \\ FR - 75205 PARIS Cedex 13 \\ E-Mail jean-yves.picard@u-psud.fr
}




\section{ABSTRACT}

Male sex differentiation is driven by two hormones, testosterone and anti-Müllerian hormone (AMH), responsible for regression of Müllerian ducts in male fetuses. Mutations inactivating AMH or its receptor AMHRII lead to the Persistent Müllerian Duct Syndrome (PMDS) in otherwise normally virilized 46,XY males. Our objective was to review the clinical, anatomical and molecular features of PMDS, based upon a review of the literature and upon 157 personal cases. Three presentations exist: bilateral cryptorchidism, unilateral cryptorchidism with contralateral hernia, and transverse testicular ectopia. Abnormalities of male excretory ducts are frequent. Testicular malignant degeneration occurs in $33 \%$ of adults with the disorder. Cancer of Müllerian derivatives is less frequent. Fertility is rare but possible if at least one testis is scrotal and its excretory ducts are intact. Eighty families with 64 different mutations of the AMH gene have been identified, mostly in exons 1, 2 and 5. AMHRII gene mutations representing 58 different alleles have been discovered in 75 families. The most common mutation, a 27 bp deletion in the kinase domain, was found in 30 patients of mostly Northern European origin. In $12 \%$ of cases, no mutation of AMH or AMHRII has been detected, suggesting a disruption of other pathways involved in Müllerian regression.

\section{INTRODUCTION}

Male sex differentiation is driven by two separate hormones [Jost, 1953], each produced by a separate cell compartment of the fetal testis. Testosterone produced by fetal Leydig cells maintains Wolffian ducts and promotes virilization of external genitalia. Anti-Müllerian hormone (AMH), a member of the TGF- $\beta$ family [Cate et al., 1986] synthesized by fetal Sertoli cells [Josso, 1973], is responsible for the regression of fetal Müllerian ducts, which in its absence would differentiate into uterus, Fallopian tubes and upper vagina. Disorders of sex development (DSD) in males may affect either one or both hormones. The persistent Müllerian duct syndrome (PMDS) belongs in the first category: AMH is either not secreted or inactive, while testosterone is normally produced and metabolized. External virilization is complete but, due to AMH deficiency, Müllerian ducts do not regress and coexist with testes and male excretory ducts. Nilson [1939] is often credited with the description of the first case but earlier publications can be found in the world literature [Jordan, 1895; Webster, 1906].

PMDS is defined as the presence of Müllerian derivatives, uterus and Fallopian tubes in otherwise normally masculinized $46, X Y$ subjects. The PMDS patient is outwardly completely male, the urethra opens at the tip of the penis (there is no hypospadias). The absence of external genital ambiguity differentiates PMDS from mixed gonadal dysgenesis, a completely different type of DSD that affects both Leydig and Sertoli cells. Until 1989, diagnosis was based exclusively upon clinical data but following the cloning of the AMH [Cate et al., 1986; Picard et al., 1986] and AMHRII [Baarends et al., 1994; di Clemente et al., 1994] cDNA and genes, it has emerged that there is not always a perfect agreement between molecular and clinical data. A few individuals with AMH or AMHRII mutations may lack Müllerian remnants, whereas in others with clinical features of the condition, no mutations can be detected.

The incidence of PMDS has not been accurately determined. It has the reputation of being a very rare condition. In fact, prior to the advent of Medline, approximately 60 publications had been collated by various authors [Royer et al., 1961; Scrivere et al., 1976; Golladay and Redman, 1982]. Two hundred more have been published between 1964 and 2012 [reviewed by Farikullah et al., 2012]. Since then, the rate has greatly accelerated with 34 new cases published over the last 4 years [reviewed by Elias-Assad et al., 2016]. The apparently increasing incidence may be due to the fact that cryptorchidism, the usual presenting symptom, is now investigated early in life, laparoscopy has become routine and more surgeons are aware of the condition now than in the past. Between 1990 and 2016 our group has performed molecular studies in 157 families with PMDS. Mutations of either the AMH or the AMH receptor type II (AMHRII) genes have been detected in $88 \%$ of 
cases. This review is based on our personal experience and upon the literature accessible to us in complete or abstract form. A chi-square test was used to compare the characteristics of patients with different genotypes.

\section{AnAtomical Features}

Position of the testes During normal male embryological development, under the influence of AMH, Müllerian ducts have totally disappeared at 10 weeks of fetal development, releasing the testes from their initial position in the pelvis and allowing them to reach the scrotum, provided the cord is of sufficient length. If the Müllerian ducts fail to regress, the testes remain suspended in the broad ligament. In females the broad ligament is solidly attached to the pelvis, but in PMDS, the connection is usually flimsy or non-existent [Miller et al., 2004], allowing the testes, still attached to the Fallopian tubes, to descend towards the inguinal canal and scrotum, dragging the uterus in their wake.

The degree of mobility of Müllerian derivatives determines the position of the testes (Fig 1). Schematically, if the uterus is fixed in the pelvis, the testes retain a high "ovarian-like" location; alternatively one or both testes may make it into the inguinal canal or the scrotum, dragging the Müllerian derivatives along. Often, one testis is contained in an inguinal hernia together with the uterus and one Fallopian tube, hence the name of "hernia uteri inguinalis" given to this condition. Inguinal hernias are very common in all forms of PMDS and may develop at any time postnatally. The anatomical condition most specific of PMDS is transverse testicular ectopia. Both testes have descended into the same hemi-scrotum and are contained in the same hernial sac, together with the uterus and tubes. Testicular fusion has been reported in this condition [Zhapa et al., 2010]

The scrotal PMDS testis is only loosely anchored to the bottom of the processus vaginalis by a thin gubernaculum resembling the round ligament of the uterus [Hutson et al., 1994]; it is abnormally mobile and easily drawn into the contralateral scrotal pouch. In two of our cases, transverse testicular ectopia was the only sign of an AMH mutation, as Müllerian derivatives had regressed normally. Rarely, one or both testes are missing in patients fulfilling the criteria for PMDS [Imbeaud et al., 1995b; Souto et al., 1995; El-Gohary, 2003]. Testicular torsion, facilitated by the abnormal mobility of the testes, has been incriminated [Chaabane et al., 2010].

There is no significant difference in anatomy between patients with either AMH or AMHRII gene mutations, and slightly more than half the patients present with bilateral cryptorchidism, a fifth with unilateral cryptorchidism and contralateral hernia and the rest with transverse testicular ectopia. In contrast, the characteristic transverse testicular ectopia has never been observed in patients with "idiopathic" PMDS, i.e. those with apparently intact AMH and AMHRII genes (Fig 2). The position of the testes/Müllerian duct complex in PMDS may differ between brothers with the same genotype [Knebelmann et al., 1990; Abduljabbar et al., 2012; Nalbantoglu et al., 2015]. In patients described in the literature in whom molecular analysis has not been performed, the proportions are not very different: $41 \%$ for bilateral cryptorchidism, $32 \%$ for hernia uteri inguinalis and $27 \%$ for transverse testicular ectopia.

Male excretory ducts The anatomy of the male excretory ducts deserves special attention. Initially the vas deferens is included in the mesosalpynx, and then reaches the uterine wall, eventually penetrating it to open at the top of the vagina, the anatomical equivalent of the prostatic utricle (Fig 1). The spermatic vessels are usually very short and must be divided at surgery to allow placement of the testis in the scrotum. This leaves the vascularization of the testis at the mercy of the deferential artery, in close proximity to the Müllerian derivatives and therefore easily damaged by attempts to remove them (see the section on Treatment). In PMDS, the vas is often abnormal, narrow, blind or even absent. Epididymal dissociation from the testis is common. Abnormalities of male excretory ducts are often reported in the literature [Bhatnagar, 1962; Binns and Cross, 1967; Scrivere et al., 1976; Sloan and Walsh, 1976; Mouli et al., 1988; Morikawa et al., 2014]. Ductal and/or epididymal abnormalities were specifically mentioned in 9 and 13 of patients with respectively $\mathrm{AMH}$ and AMHRII mutations and in 2 idiopathic cases with no detected molecular defects. However, ductal and 
epididymal anomalies are commonly associated with cryptorchidism, particularly its abdominal variant, even in the absence of PMDS [Mollaeian et al., 1994; Sharma and Sen, 2013].

Müllerian derivatives The development of Müllerian derivatives is extremely variable, even between brothers. The uterus may be comparable in size to that of normal females but it is often much smaller. Uterus and tubes are often contained in an inguino-scrotal hernia where they are easily detectable at surgery. However, when the uterus is retained in the pelvis, its presence can be missed [El-Gohary, 2003; Farikullah et al., 2012; Goto et al., 2012] as seen in several of our patients. The Müllerian ducts enter the upper urethra at the level of the prostate but the communication is often obliterated. Sometimes, Müllerian derivatives are not found in subjects bearing an AMH or AMHRII mutation. They may be totally asymptomatic [Abduljabbar et al., 2012] or present with isolated transverse testicular ectopia.

\section{CLINICAL FEATURES}

In children, PMDS is usually discovered at surgery or laparoscopy motivated by cryptorchidism with or without inguinal hernia (Fig 3). Unilateral or bilateral cryptorchidism are not particularly evocative although unilateral cryptorchidism with contralateral hernia and particularly transverse testicular ectopia should awake suspicion. If a sibling has been diagnosed with the condition, imaging investigations should be scheduled [Di et al., 1998; Di Cesare et al., 1998; Dekker et al., 2003]. Ultrasonography of the scrotum and pelvis is generally sufficient to suspect PMDS, but magnetic resonance imaging could be necessary to recognize the different structures. Occasionally, the patient has a history of a previous surgical procedure for hernia or inguinal cryptorchidism. Adults in whom cryptorchidism or inguinal hernia have been disregarded may come to medical attention because of hematuria due to hormonal imbalance in aging patients whose testes produce less androgens and an excessive amount of estrogens [Gricourt et al., 2010]. Cyclic hematuria led to the discovery of PMDS in a 27year old patient with no apparent hormonal abnormalities [Smith-Harrison et al., 2015]. More often, discovery of PMDS is contingent upon the development of testicular or Müllerian malignancies.

Malignant degeneration. Nowadays in developed countries, cryptorchidism is treated as early as possible to avoid damage to germ cells but formerly, this was usually not the case. Adult PMDS patients were often diagnosed because of malignant degeneration of the testes or the Müllerian remnants. The incidence of testicular cancer in PMDS has been formerly estimated at 18\%, no higher than the risk for cryptorchid testes in general [Bucci et al., 2002; Shamim, 2007]. Our own perusal of the literature yields a much higher figure: $33 \%$ of PMDS patients 18 years and older experienced some form of unilateral or bilateral malignant testicular degeneration. Seminomas are the most frequent, but choriocarcinomas [Giri et al., 2004; Aboutorabi et al., 2005], mixed germ cell tumors [Eastham et al., 1992; Manassero et al., 2004; Jaka and Shankar, 2007; Mohapatra and Subramanya, 2016] embryonal cell carcinoma [Melman et al., 1981; Carré-Eusèbe et al., 1992; Barad et al., 2016] gonadoblastomas [Morillo-Cucci and German, 1971] or yolk sac tumor [Snow et al., 1985] have also been described. In our own cohort, we encountered 3 testicular tumors (H069 and H050) [CarréEusèbe et al., 1992] and H009, all adults with AMH mutations (see Suppl. Table 1). Young patients may be affected by germ cell neoplasia in situ, as seen by Williams et al [1994] in a 17-year-old patient and by ourselves in a 15 month-old boy with a receptor defect (R031) (Suppl. Table 2). Early orchidopexy is recommended to preserve against testicular degeneration but is not necessarily $100 \%$ effective. Melman et al [1981] have reported embryonal carcinoma in a 16-year-old boy who had undergone bilateral orchidopexy at 2 months of age. Likewise, Manassero et al [2004] observed a mixed germ cell tumor in a 23-year old patient operated at 5 years of age for transverse testicular ectopia. These observations, in addition to the abnormally high incidence of testicular cancer in PMDS compared to simple cryptorchidism, suggests that misplacement of the testis may not be the only factor favoring malignant degeneration in this disorder. In mice, deletion of the $\mathrm{AMH}$ [Behringer and Cate, 1994; Matzuk et al., 1995] or AMHRII gene [Tanwar et al., 2012] facilitates testicular tumors induced by respectively inhibin suppression or WT1/ $\beta$-catenin imbalance. Prognosis depends upon the 
histological type of the tumor, choriocarniomas [Giri et al., 2004; Aboutorabi et al., 2005] and mixed germ cell tumors [Manassero et al., 2004; Jaka and Shankar, 2007] share a poor prognosis.

Malignant degeneration of Müllerian derivatives is much less frequent. Farikullah et al. [2012] found 11 cases of male Müllerian duct degeneration in the literature but only 3 qualified as PMDS. The rest were so-called "Müllerian" cysts, i.e. prostatic utricle cysts [Kato et al., 2002] which arise at the site of confluence between the urogenital sinus, the Müllerian and the Wolffian ducts [Glenister,1962]. Hematuria is often the presenting sign [Thiel and Erhard, 2005]. Two young men with uterine adenocarcinoma died from metastatic disease one at 14 years of age [Thiel and Erhard, 2005] and the other at age 39 [Romero et al., 2005]. An additional patient [Kovachev et al., 2014] was diagnosed with a benign uterine leiomyoma.

Infertility is the most frequent complication of PMDS. In our personal experience, only one patient with an AMH mutation, (H071), fathered a child after testicular sperm extraction motivated by oligo and asthenozoospermia. We noted similar sperm defects in two other patients, one with an AMH and two with an AMHRII mutation [Zeller et al., 1994]. In the literature, sterility is indeed the rule but normal spermatogenesis has been reported. A thorough literature search found that $19 \%$ of reported adult patients fathered one or more children [Karimi-Nejad et al. 1988; Farag, 1993; Berkmen, 1997; Aboutorabi et al., 2005; Liang et al., 2006; Jaka and Shankar, 2007; Prakash et al., 2009; Sichani et al., 2009; Inuganti et al., 2011; Kaore and Kaore, 2012; Kumar and Mohan, 2012; Kovachev et al., 2014; Sherwani et al., 2014; Agrawal and Kataria, 2015; Modi et al., 2015]. Farag et al [1993] reported an 11\% proportion of fertile patients in Kuwait and neighboring populations. All these patients except one [Modi et al., 2015] presented with either transverse testicular ectopia or hernia uteri inguinalis, i.e. at least one testis was in a normal scrotal position. Proof of paternity was not provided but it is unlikely that all births could be the result of extra-conjugal relationships, particularly since many of the reports originated from countries where contact between the sexes is strongly discouraged outside of matrimony. We conclude that fertility is rare but possible in PMDS provided two conditions are met : at least one testis should be normally descended and the excretory ducts should be intact. All fertile PMDS patients fathered children before their condition had been diagnosed. Late diagnosis carries a price, however: many of these patients developed testicular cancer. PMDS dogs with uni or bilateral scrotal testes are also fertile [Meyers-Wallen et al., 1989].

Congenital malformations associated with PMDS. Various congenital abnormalities have been described in association with PMDS. Intestinal defects such as atresia or lymphangectasia (Urioste syndrome) were described in 4 cases [Klosowski et al., 1997; Bellini et al., 2001; vanHaelst et al., 2001]. Hirschsprung's disease [Cass and Hutson, 1992], horseshoe kidney [Barad et al., 2016] or mental deficiency [Snow et al., 1985], lipodystrophy and vitamin D-resistant rickets [Van Maldergem et al., 1996], renal polykystosis, hydronephrosis or deafness may also be present, as well as prematurity or small for gestational age syndrome. In our experience, in patients with associated malformations AMH or AMHRII mutations are seldom detected.

\section{ENDOCRINE INVESTIGATIONS}

Endocrine investigations in PMDS usually show that Leydig cell function is normal, except in patients with testicular degeneration [Imbeaud et al., 1995b]. The AMH concentration in serum depends upon the molecular origin of the disorder. Very low or undetectable serum AMH concentrations in prepubertal boys are characteristic of mutations of the gene coding $\mathrm{AMH}$. Low $\mathrm{AMH}$ concentration in post-pubertal and, to a lesser degree, newborn males is physiological [Grinspon et al., 2011] and should not be interpreted as pointing to an $\mathrm{AMH}$ mutation. AMH serum concentration may be decreased immediately after surgery. In patients with virilizing defects such as hypospadias, low AMH reflects testicular dysgenesis, not to be confused with PMDS. Normal values of serum AMH in developing boys are shown in the Table. AMH was measured in the serum of all our cases by the referring physician. The results are not comparable because they were obtained with different methods [Nelson et al., 2015]. 
Normal AMH levels usually exclude an AMH mutation, with the exception of AMH mutation p.(Gln496His) which is thought to affect receptor binding [Belville et al., 2004]. The sequence variations reported in an Italian patient [Menabo et al., 2008] with a normal serum AMH level could be innocuous, and an AMHRII mutation cannot be ruled out because the gene was not sequenced. Normal for age levels of circulating $A M H$ are characteristic of AMHRII mutations, and circulating levels of $\mathrm{AMH}$ are usually not increased, as is the case in androgen insensitivity. However, receptor mutations are not always detectable in PMDS patients with normal levels of serum AMH. Idiopathic PMDS is described below.

\section{INHERITANCE}

PMDS is an inherited disease transmitted as an autosomal recessive trait explained by the location of the AMH gene on the short arm of chromosome 19 [Cohen-Haguenauer et al., 1987] and that of the AMHRII gene on the long arm of chromosome 12 [Imbeaud et al., 1995a]. The rate of consanguinity is high: $40 \%$ and $33 \%$ in families with respectively $\mathrm{AMH}$ and $\mathrm{AMHRII}$ mutations but only $10 \%$ in idiopathic PMDS. The rate of homozygosity varies in different parts of the world but is grossly the same for AMH and AMHRII mutations, respectively $65 \%$ and $57 \%$ (Fig 4 ).

Two reports [Sloan and Walsh, 1976; Naguib et al., 1989] raise the possibility that PMDS may sometimes be transmitted as an X-linked condition but they are difficult to interpret in highly inbred communities [Naguib et al., 1989] since many family members might carry the pathological allele. Heterozygous subjects with one normal allele are clinically normal. There is no phenotype in females. Homozygous sisters and, in one instance, the homozygous mother of a PMDS propositus (H066), are normal and fertile. AMH-null female mice experience early depletion of their follicular pool [Durlinger et al., 1999]. Possibly, women homozygous for AMH or AMHRII mutations will undergo premature menopause, but this cannot be verified at the present time.

\section{TREATMENT}

Treatment aims at the prevention of the two main complications of PMDS: infertility and cancer. Paradoxically, as mentioned above, the best chances of fertility are sustained by patients having escaped treatment altogether but this is no longer likely because cryptorchidism and inguinal hernia are now surgically corrected in early childhood. The surgeon should bear in mind that the male excretory ducts are in close apposition to or even enclosed in the walls of the Müllerian derivatives thus any attempt to remove the Müllerian organs in toto will automatically damage the vas deferens or the deferential artery. Why then not leave them in place? For several reasons: they may, although rarely, undergo malignant degeneration (see above) or cause discomfort or hematuria in the event of estrogen excess [Gricourt et al., 2010]. However, the main reason for hysterectomy is mechanical. When both testes are in an abdominal position, the uterus blocks testicular descent and orchidopexy is impossible. To overcome this difficulty, the fundus of the uterus can be split in the midline [Brandli et al., 2005; Manjunath et al., 2010] and the uterine walls carefully dissected to free the vas. The magnification provided by laparoscopy is helpful in this respect [Farikullah et al., 2012]. Alternatively, the uterus can be stripped of its mucosal lining to reduce the risk of malignant degeneration [Manjunath et al., 2010]. Abnormalities of male excretory ducts, whether congenital or iatrogenic, are treatable by testicular sperm extraction followed by intracytoplasmic sperm injection if fertility is desired, this procedure was successful in patient H071 (Suppl. Table 1)

The uterus is not the only obstacle to testicular descent. When testes are in a high abdominal position, the cord is often much too short to allow placement of the testis in the scrotum. The internal spermatic artery must then be divided and testicular viability becomes dependent on the deferential artery. To minimize the risk to this vessel, pedicles of myometrium should be left adhering to the vasa and the fimbriae of the Fallopian tube should not be dissected from the testis [Vandersteen et al., 1997]. As an alternative to the FowlerStephens procedure, microvascular autotransplantation of the testis has been successfully performed [Brandli 
et al., 2005]. Most of these procedures can be carried out by laparoscopy [Bowen et al., 2016] or robotic surgery [Smith-Harrison et al., 2015].

Testicular biopsy is unnecessary provided the diagnosis of PMDS is not in doubt. In children, testicular morphology is normal [Loeff et al., 1994; van der Zwan et al., 2012], and this is also our experience. In older patients, testes are often hypoplastic with tubular fibrosis, thickened basal membrane and no spermatogenesis [Mouli et al., 1988]. If the testes cannot be brought down, orchidectomy is recommended to avoid future malignant degeneration but should be considered only as a last resort. Obviously, there is no justification for castration in children without any attempt at orchidopexy [Guell-Gonzalez et al., 1970; Armendares et al., 1973]. A horrifying report from Pakistan [Kaore and Kaore, 2012] relates an en bloc removal of uterus and scrotal testes in a fertile 35-year old man with transverse testicular ectopia; such mutilations are thankfully exceptional.

\section{Molecular Studies}

In our experience, mutations of the AMH or the AMHRII gene are responsible for $88 \%$ of PMDS cases; the others have no identified molecular cause and are presently labelled "idiopathic".

\section{AMH GENE MUTATIONS}

$\mathrm{AMH}$, a glycoprotein dimer belonging to the TGF- $\beta$ family [Cate et al., 1986] is coded by a 5 exon gene $2.8 \mathrm{kbp}$ long, located on the short arm of chromosome 19 p.13.3 [Cohen-Haguenauer et al., 1987]. AMH, like other members of the family is translated as a dimeric precursor comprising two polypeptide chains, each containing a large N-terminal pro-region and a much smaller C-terminal mature domain which shows homology with the other members of the family and carries the bioactivity of the molecule. Cleavage at arginine 451 yields 110 kDa N-terminal and 25 kDa C-terminal dimers which remain associated in a bioactive non-covalent complex [Pepinsky et al., 1988]. While cleavage is obligatory, dissociation of the two fragments is not required for binding to the receptor and subsequent biological activity [di Clemente et al., 2010] (Figure 5). In the absence of the N-terminal fragment the C-terminus cannot fold properly and is rapidly degraded prior to secretion, explaining the pathogenicity of $\mathrm{N}$-terminal mutations.

Patients with AMH mutations are described in Supplemental Table 1. The first one, a Stop mutation of the 5th exon affecting the $\mathrm{N}$-terminal domain, was detected in 1989 in three brothers belonging to a Moroccan family [Knebelmann et al., 1990]. Since then, we ourselves have identified 68 families with AMH mutations; 12 have been described by other groups [Mazen et al., 2011; Nishi et al., 2012; van der Zwan et al., 2012; Morikawa et al., 2014; Nalbantoglu et al., 2015; Mazen et al., 2016]. 65\% of mutations are homozygous reflecting a high rate of inbreeding in some parts of the world (Fig 4). Given the high value placed on fertility in the culture of these populations, we recommend genetic testing in the relatives of PMDS patients with identified AMH or AMHRII mutations and their prospective partners, if marriage is contemplated. In six instances, only one abnormal allele could be identified. The most likely explanation is that the other escaped detection, perhaps because it is located in the center of an intron or for technical reasons. The AMH gene is difficult to sequence because it is very rich in guanine and cytosine bases.

Altogether, a total of 64 different pathogenic AMH alleles have been identified in 80 families: 37 missense, 10 Stop and one non-stop p.(*561Cysext*?), 9 deletions (including one insertion/deletion (H031), 2 insertions and 5 splicing mutations (Suppl. Fig. 1). Mutations occur along the whole length of the gene though exon 4 is very rarely involved (Fig. 6A); exons 1 and 2 are proportionally the most affected. In exon 5, the bases coding the biologically active $\mathrm{C}$-terminus are hit at nearly three times the rate of the $\mathrm{N}$-terminal ones. There are no significant "hotspots" though many mutations are recurrent (Fig. 7A). Six have been found in 4 or more families while 13 others have occurred less frequently. Intron 2 is the target of two distinct recurrent splicing mutations, the first affecting the donor and the second one the acceptor site. The latter, a A>G change at the 
penultimate base of the $2^{\text {nd }}$ intron, was found in three unrelated Brazilian patients and may represent a founder effect [Nishi et al., 2012]. Similarly, the four families affected by mutation c.301G>A, p.(Gly101Arg) all originate from the Middle East or Pakistan [Abduljabbar et al., 2012]. The five families affected by mutation c.500A>G, p.(Tyr167Cys) are Northern European.

Belville et al [2004] have studied the biosynthesis and secretion of seven mutant AMH proteins. Those lacking a $\mathrm{C}$-terminal domain are secreted more rapidly whereas single amino acid changes in either the $\mathrm{C}$ - and the $\mathrm{N}$ terminal domain have significant effects upon protein stability and folding. Addition or elimination of cysteines are particularly damaging.

Alleles deserving a special mention are shown on Fig. 7A.

A deletion within the promoter, 225 bp upstream from the initiating ATG, results in the loss of the $4^{\text {th }}$ base of the SF1 response element, TCAAGGACAG [Valeri et al., 2016]. The AMH promoter carries two SF1 response elements, a proximal one at -102 from the ATG [Shen, 1994] and a distal one at -228 [Watanabe et al., 2000]. Both sites are involved in the upregulation of AMH gene expression in cultured Sertoli cells [Shen et al., 1994; Lasala et al., 2011]. In transgenic mice Arango et al [1999] found that inactivation of the proximal site did not prevent Müllerian duct regression. The persistence of Müllerian derivatives in our patient shows that the distal SF1 response element is absolutely required for significant human $\mathrm{AMH}$ expression.

Another mutation, c.3G>T, observed in a Moroccan patient, $\mathrm{H} 002$, changes the translation initiation codon ATG for methionine into ATT, coding for isoleucine. The molecular effect of the mutation is not known. Kozak [Kozak, 2002] has shown that proximity to the $5^{\prime}$ end plays a dominant role in identifying the start codon. If the canonical start site is destroyed, translation may initiate at the next available ATG. However, in the AMH protein the next ATG at position 191 is not in frame and the next in frame ATG is far downstream in exon 4. It is highly unlikely that either could allow translation of a functional protein [Mentrup et al., 2011]. Most start codon mutations result in complete absence of the affected protein [Sargiannidou et al., 2015; Jinda et al., 2016].

The "nonstop" mutation c.1683A>T changes the stop codon TGA into TGT the cysteine codon. No downstream in frame stop codon is present in the 3 'untranslated region before the polyadenylation site, suggesting that the translated protein must be significantly extended. However, such extra large proteins are usually not produced because of ribosome stalling at the $3^{\prime}$ end of the mutated mRNA, which blocks translation before the full-length polypeptide can be synthesized [Hamby et al., 2011]. A recurrent mutation c.35 T>G [Imbeaud et al., 1994] leads to the replacement of valine by glycine at position $12 \mathrm{p}$.(Val12Gly), in the midst of the signal sequence.

The DNA of patient H075 carries two homozygous mutations, p.(Ala314Gly) and p.(Gly533Val), none of which correspond to recognized polymorphisms. His serum AMH level was very low. Gly533 is located in the $\beta 6$ strand of the mature domain (Fig. 8). The $\beta$ sheet structure would probably not be disrupted by a valine substitution, in fact quite the opposite could occur. Glycine is an intrinsically destabilizing residue in $\beta$ sheets [Merkel and Regan, 1998] and its presence in the $\beta$ strands of several natural proteins might be due to its ability to inhibit aggregation and formation of amyloid fibrils [Parrini et al., 2005]. Thus the Gly533Val mutant protein might be less stable and prone to aggregation. The fact that Gly533 is conserved in AMH across species provides support for this hypothesis. The role, if any, of the Ala314Gly mutation, located in the $\beta 7$ strand of the pro-region, is not clear. The replacement of Ala314, which is strongly conserved across species, by glycine could destabilize the $\beta$ sheet and thereby add to the instability of the double mutant protein, but no conclusions can be drawn in the absence of experimental data. By comparison to a molecular model of the BMP9 noncovalent complex [Mi et al., 2015], it can be inferred that the $\beta 7$ strand in the pro-region is too far away from the cleavage site at Arg451 to interfere with processing.

The impact of splicing mutations cannot be assessed in the absence of mRNA. In the male, AMH is expressed nearly exclusively in testicular Sertoli cells. When tissues normally expressing a protein of interest are not 
available, "illegitimate" transcription may be successful [Chelly et al., 1989]. In patient H044, we were able to obtain AMH mRNA by amplifying a discrete RT-PCR product obtained from uterine mRNA primed for reverse transcription. Sequencing of AMH mRNA revealed retention of the first 46 bases of intron 1 and use of a downstream cryptic donor site at position +47 in intron 2 [Gricourt et al., 2010).

The polymorphism c.146T>G, p.(Ile49Ser) seen in $21 \%$ of normal subjects is identical to the sequence of bovine $\mathrm{AMH}$. For this reason, it is not expected to affect $\mathrm{AMH}$ bioactivity. In normal women it is associated with higher levels of estradiol at the follicular phase of the menstrual cycle, suggesting a role in ovarian sensitivity to FSH [Kevenaar et al., 2007a].

\section{AMH RECEPTOR MUTATIONS}

Like other member of the TGF- $\beta$ family, AMH signals through two membrane-bound serine/threonine kinase receptors type I and type II. Paradoxically the type II receptor, AMHRII, is the primary one and is AMH-specific. AMHRII binds AMH after the latter has undergone proteolytic cleavage at Arg 451, and then activates a type I receptor, ALK 2, 3 or 6 . This leads to the phosphorylation of R-Smad proteins 1, 5 or 8 , its interaction with Smad4 and the translocation of the R-Smad/Smad4 complex to the nucleus where it promotes or more likely represses the transcription of target genes (Fig. 9). AMH shares its type I receptors, and its R-Smad effectors, with the bone morphogenetic proteins (BMPs) [reviewed in Orvis et al., 2008]. Since the BMP pathway is required for early embryonic development, it cannot be involved in isolated PMDS and so the only possible culprit is the specific AMH type II receptor, AMHRII. AMHRII is a 573 amino acid membrane protein containing an $\mathrm{N}$-terminal extracellular domain that binds $\mathrm{AMH}$, a single transmembrane domain, and an intracellular domain with serine/threonine kinase activity. The AMHRII gene, located at 12q13 [Imbeaud et al., 1995a] contains 11 exons spread over $8 \mathrm{kbp}$. The first three encode the extracellular domain which binds cleaved AMH [di Clemente et al., 2010], the fourth encodes the transmembrane domain and the last seven exons encode the catalytic intracellular serine/threonine domain (Fig. 7B). The level of bioactive AMH in biological fluids can be assessed by monitoring their capacity to bind to AMHRII [Pierre et al., 2016].

There is no phenotypic difference between patients with either AMH or AMHRII mutations (Fig. 2), confirming the monogamic relationship between $\mathrm{AMH}$ and its type II receptor [Mishina et al., 1999]. Patients with AMH receptor mutations are described in Supplemental Table 2. The first one was described in 1995 [Imbeaud et al., 1995a]. Since then a total of 75 families with PMDS due to AMHRII mutations have been identified, 68 by our group. The other cases were reported in the USA [Hoshiya et al., 2003], Brazil [Nishi et al., 2012], Egypt [Mazen et al., 2016], Portugal [Rosal-Gonçalves et al., 2010], Turkey [Korkmaz et al., 2017] and Israel [Elias-Assad et al., 2016]. A total of 58 different alleles have been identified: 35 missense, 11 stop, 8 deletions, and 4 splicing defects (Suppl. Fig. 2). All 11 exons are affected (Fig 6B). Two different mutations of the initiation codon were observed (R001 and R002) (Fig 7B) with unknown consequences. The next methionine is at position 76, probably too far downstream to initiate translation (see section on AMH mutations). Patient R024 was initially considered to be homozygous for c.532C $>\mathrm{T}$, p. $\left(\operatorname{Arg} 178^{*}\right)$. However, while the father was heterozygous as expected, surprisingly, only the normal allele could be detected in the mother. To explain this paradox, we hypothesized that she was heterozygous for a large deletion of all or part of the AMHRII gene. This hypothesis has been confirmed [Lucie Tosca and Gérard Tachdjian, personal communication]; studies are in progress to determine the extent of the deletion.

Ten recurrent mutations have been identified (Fig 7B). The most frequent, a deletion of 27 base pairs in exon 10, c.1332_1358del, p.(Gly445_Leu453del) according to the present official nomenclature, was initially considered to result in p.(Leu444_Glu452del) [Imbeaud et al., 1996]. It has been observed in 30 patients, 67\% of whom are Northern Europeans, a proportion significantly different from the $36 \%$ of that origin in the 75 patients with AMHRII mutation $(p<0.05)$, suggesting a founder effect. Twenty out of 27 Northern European patients carry the deletion, compared to only one out of 11 Southern Europeans. The deletion can be recognized by PCR (Fig. 10). When a receptor mutation is suspected, we recommend performing this procedure 
as a first line investigation. Other recurrent mutations are much less prevalent. The c.1219C $>\mathrm{T}$ mutation, resulting in the change of arginine at position 407 to a Stop codon, has been observed in 6 families, 4 from Mediterranean countries, 1 from Saudi Arabia and one Brazilian patient of undisclosed ancestry. The number of families affected by the other recurrent mutations is too small to allow geographical analysis.

Belville et al. [2009] have studied the impact of receptor mutations upon expression, stability and secretion. Interestingly, in contrast to other receptors of the TGF $\beta$ family, mutations of the extracellular domain which truncate the transmembrane domain just upstream of the transmembrane domain are not secreted, unless the endogenous signal sequence is replaced with that of the TGF $\beta$ receptor type II, indicating that the AMHRII signal sequence is defective. This likens AMHRII to a type III membrane protein, whose transmembrane domain acts like a signal anchor directing the $\mathrm{N}$-terminal end of the protein to the outside of the cell [Goder and Spiess, 2001]. Like similar receptors of the TGF $\beta$ family, these receptors are dominant negative when overexpressed but in vivo, only siblings carrying the mutation on both alleles are affected by PMDS, presumably because the mutant and wild-type allele are expressed at a one to one ratio [Messika-Zeitoun et al., 2001].

Missense mutations in the extracellular domain cannot be analyzed reliably because of low sequence identity $(<20 \%)$ between AMHRII and the receptor templates used to construct the three-dimensional model [Belville et al., 2009]. In the intracellular domain, two AMHRII mutants, c.596delA and the frequent allele c.1332_1358del, p.(Gly445_Leu453del) lack all of the kinase domain or contain a critical deletion. The p.(Gly445-Leu453del) mutation results in a deletion of nine amino acids that constitute part of the $\alpha \mathrm{G}$ helix and the loop that precedes it (Fig. 11A). In eukaryotic protein kinases, helices $\alpha \mathrm{G}, \alpha \mathrm{H}$ and $\alpha \mathrm{l}$ have coevolved together with the Activation segment (Fig. 11B) and contribute to an important regulatory mechanism [Taylor and Kornev, 2011]. Mutations that disrupt communication between these two conserved elements have been shown to have severe effects on catalytic activity [Yang et al., 2012]. p.(Arg406Gln), p.(Asp491His) and p.(Arg504Cys) or p.(Arg504His) affect residues conserved in all type II receptors of the TGF $\beta$ family.

Incidentally, in women, a promoter A>G polymorphism, $-482 \mathrm{bp}$ from the ATG, is associated with follicular estradiol levels [Kevenaar et al., 2007a] and age at menopause [Kevenaar et al., 2007b]. A receptor mutation in exon 3, p.Arg81Stop, is responsible for PMDS in miniature Schnauzer dogs [Pujar and Meyers-Wallen, 2009; Wu et al., 2009], but the molecular defect in the Basset Hound with PMDS has not been elucidated [Nickel et al., 1992]. AMH and AMHRII mutations have also been identified in European bisons with persistent Müllerian derivatives [Panasiewicz et al., 2015].

\section{IDIOPATHIC PMDS}

In approximately $12 \%$ of our PMDS cases, we have been unable to detect mutations in either the $\mathrm{AMH}$ or the AMHRII genes. We cannot exclude that some escaped our notice, particularly in patients studied several years ago with less effective sequencing methods. Mutations in the distal promoter or central introns would not have been detected either, for instance the receptor splice mutation described by Hoshiya [Hoshiya et al., 2003] would not have been identified in our laboratory. Another possibility is that "idiopathic" PMDS represents a separate entity. We favor this hypothesis because of the marked clinical differences between it and the syndrome due to $\mathrm{AMH}$ or AMHRII mutations. Associated malformations are frequent, the characteristic transverse testicular ectopia is not observed (Fig. 2) and the rate of consanguinity is low. Screening for other genetic alterations is planned in the few cases with sufficient DNA left for study.

Multiple genetic pathways implicated in Müllerian development have been invoked [Mullen and Behringer, 2014], namely the Wnt pathway. Wnt4 is required for Müllerian duct development in both sexes [Vainio et al., 1999]; Wnt7 triggers the expression of AMHRII in the Müllerian duct mesenchyme, in its absence Müllerian ducts do not regress in the male [Parr and McMahon, 1998]. AMH signaling induces the translocation of $\beta$ catenin and the accumulation of lymphocyte enhancer factor 1 (LEF1) in the nucleus of mesenchymal cells [Allard et al., 2000]. Normal AMH regression does not occur in male mice in which $\beta$-catenin has been 
inactivated [Kobayashi et al., 2011]. The postulated mechanisms of interaction between the Wnt and AMH pathway are shown in Figure 9. Modern methods of genetic investigation [Bashamboo et al., 2010; Eggers et al., 2016] applied to idiopathic PMDS will probably produce unexpected results. 


\section{Reference List}

Abduljabbar M, Taheini K, Picard JY, Cate RL, Josso N: Mutations of the AMH type II receptor in two extended families with Persistent Mullerian Duct Syndrome: lack of phenotype/genotype correlation. Horm Res Paediatr 77:291-297 (2012).

Aboutorabi R, Feizzadeh B, Rajabian R: Gynecomastia secondary to choriocarcinoma in a man with persistant Müllerian duct syndrome. Int J Endocrinol and Metab 3:140-142 (2005).

Agrawal AS, Kataria R: Persistent Mullerian Duct Syndrome (PMDS): a rare anomaly the general surgeon must nnow about. Indian J Surg 77:217-221 (2015).

Allard S, Adin P, Gouédard L, di Clemente N, Josso N, Orgebin-Crist MC, Picard JY, Xavier F: Molecular mechanisms of hormone-mediated Müllerian duct regression : involvement of beta-catenin. Development 127:3349-3360 (2000).

Arango NA, Lovell-Badge R, Behringer RR: Targeted mutagenesis of the endogenous mouse Mis gene promoter: In vivo definition of genetic pathways of vertebrate sexual development. Cell 99:409-419 (1999).

Armendares S, Buentello L, Frenk S: Two male sibs with uterus and Fallopian tubes. A rare, probably inherited disorder. Clin Genet 4:291-296 (1973).

Baarends WM, van Helmond MJL, Post M, van der Schoot PCJM, Hoogerbrugge JW, De Winter JP, Uilenbroek JTJ, Karels B, Wilming LG, Meijers JHC, Themmen APN, Grootegoed JA: A novel member of the transmembrane serine/threonine kinase receptor family is specifically expressed in the gonads and in mesenchymal cells adjacent to the Müllerian duct. Development 120:189-197 (1994).

Barad AK, Bharath NM, Narayana V, Raja VO, Jambula PR: Persistent Mullerian Duct Syndrome with embryonal cell carcinoma along with ectopic cross fused kidney. J Clin Diagn Res 10:D07-D08 (2016).

Bashamboo A, Ledig S, Wieacker P, Achermann J, McElreavey K: New technologies for the identification of novel genetic markers of disorders of sex development (DSD). Sex Dev 4:213-224 (2010).

Behringer RR and Cate RL. (1994). Müllerian inhibiting substance function during mammalian reproductive development. In Cell and molecular biology of the testis, M.L.Dufau, ed. (Rome: Ares-Serono Symposia Publications), pp. 1-6.

Bellini C, Bonioli E, Josso N, Belville C, Mazzella M, Costabel S, Sementa AR, Marino CE, Toma P, Hennekam RC, Serra G: Persistence of Mullerian derivatives and intestinal lymphangiectasis in two newborn brothers: confirmation of the Urioste syndrome. Am J Med Genet 104:69-74 (2001).

Belville C, Maréchal JD, Pennetier S, Carmillo P, Masgrau L, Messika-Zeitoun L, Galey J, Machado G, Tréton D, Gonzalès J, Picard JY, Josso N, Cate RL, di Clemente N: Natural mutations of the anti-Müllerian hormone type II receptor found in persistent Müllerian duct syndrome affect ligand binding, signal transduction and cellular transport. Hum Mol Genet 18:3002-3013 (2009).

Belville C, Van Vlijmen H, Ehrenfels C, Pepinsky RB, Rezaie AR, Picard JY, Josso N, di Clemente N, Cate RL: Mutations of the anti-Müllerian hormone gene in patients with persistent Müllerian duct syndrome : biosynthesis, secretion and processing of the abnormal proteins and analysis using a three-dimensional model. Mol Endocrinol 18:708-721 (2004).

Berkmen F: Persistent mullerian duct syndrome with or without transverse testicular ectopia and testis tumours. Br J Urol 79:122-126 (1997). 
Bhatnagar KK: Uterus presenting in an inguinal hernia of a male subject. Br Med J 2:1236 (1962).

Binns JH, Cross RM: Hernia uteri inguinalis in a male. Br J Surg 54:571-575 (1967).

Bowen DK, Matulewicz RS, Gong EM: Preservation of mullerian structures with laparoscopic management of intra-abdominal testes in persistent mullerian duct syndrome. J Pediatr Urol 12:65-66 (2016).

Brandli DW, Akbal C, Eugsster E, Hadad N, Havlik RJ, Kaefer M: Persistent Mullerian duct syndrome with bilateral abdominal testis: Surgical approach and review of the literature. J Pediatr Urol 1:423-427 (2005).

Bucci S, Liguori G, Buttazzi L, Bussani R, Trombetta C: Bilateral testicular carcinoma in patient with the persistent Müllerian duct syndrome. J Urol 167:1790 (2002).

Carré-Eusèbe D, Imbeaud S, Harbison M, New MI, Josso N, Picard JY: Variants of the anti-Müllerian hormone gene in a compound heterozygote with the persistent Müllerian duct syndrome and his family. Hum Genet 90:389-394 (1992).

Cass DT, Hutson J: Association of Hirschsprung's disease and Mullerian inhibiting substance deficiency. J Pediatr Surg 27:1596-1599 (1992).

Cate RL, Mattaliano RJ, Hession C, Tizard R, Farber NM, Cheung A, Ninfa EG, Frey AZ, Gash DJ, Chow EP, Fisher RA, Bertonis JM, Torres G, Wallner BP, Ramachandran KL, Ragin RC, Manganaro TF, MacLaughlin DT, Donahoe PK: Isolation of the bovine and human genes for Müllerian inhibiting substance and expression of the human gene in animal cells. Cell 45:685-698 (1986).

Chaabane W, Jarboui L, Sahnoun A, Daoud E, Hadjsliman M, Fakhfekh H, Bahloul A, Mhiri MN: Persistent Mullerian duct syndrome with torsion of a transverse testicular ectopia: first reported case. Urology 76:65-66 (2010).

Chelly J, Concordet JP, Kaplan JC, Kahn A: Illegitimate transcription - transcription of any gene in any cell type. Proc Natl Acad Sci (USA) 86:2617-2621 (1989).

Cohen-Haguenauer O, Picard JY, Mattei MG, Serero S, Nguyen VC, de Tand MF, Guerrier D, Hors-Cayla MC, Josso N, Frézal J: Mapping of the gene for anti-Müllerian hormone to the short arm of human chromosome 19. Cytogenet and Cell Genet 44:2-6 (1987).

Dekker HM, de Jong IJ, Sanders J, Wolf RF: Persistent Mullerian duct syndrome. Radiographics 23:309-313 (2003).

Di Cesare E, Di Bartolo DV, V, Maffey MV, Splendiani A, Masciocchi C: US and MRI in a case of persistent Mullerian duct syndrome. Pediatr Radiol 28:865-867 (1998).

di Clemente N, Jamin SP, Lugovskoy A, Carmillo P, Ehrenfels C, Picard JY, Whitty A, Josso N, Pepinsky RB, Cate RL: Processing of anti-mullerian hormone regulates receptor activation by a mechanism distinct from TGF-?? Mol Endocrinol 24:2193-2206 (2010).

di Clemente N, Wilson CA, Faure E, Boussin L, Carmillo P, Tizard R, Picard JY, Vigier B, Josso N, Cate RL: Cloning, expression and alternative splicing of the receptor for anti- Müllerian hormone. Mol Endocrinol 8:1006-1020 (1994).

Di CE, Di Bartolo DV, V, Maffey MV, Splendiani A, Masciocchi C: US and MRI in a case of persistent Mullerian duct syndrome. Pediatr Radiol 28:865-867 (1998).

Durlinger ALL, Kramer P, Karels B, de Jong FH, Uilenbrok JTJ, Grootegoed JA, Themmen APN: Control of primordial follicle recruitment by anti-Müllerian hormone in the mouse ovary. Endocrinology 140:5789-5796 (1999). 
Eastham JA, McEvoy K, Sullivan R, Chandrasoma P: A case of simultaneous bilateral nonseminomatous testicular tumors in persistent mullerian duct syndrome. J Urol 148:407-408 (1992).

Eggers S, Sadedin S, Van Den Bergen JA, Robevska G, Ohnesorg T, Hewitt J, Lambeth L, Bouty A, Knarston IM, Tan TY, Cameron F, Werther G, Hutson J, O'Connell M, Grover SR, Heloury Y, Zacharin M, Bergman P, Kimber C, Brown J, Webb N, Hunter MF, Srinivasan S, Titmuss A, Verge CF, Mowat D, Smith G, Smith J, Ewans L, Shalhoub C, Crock P, Cowell C, Leong GM, Ono M, Lafferty AR, Huynh T, Visser U, Choong CS, McKenzie F, Pachter N, Thompson EM, Couper J, Baxendale A, Gecz J, Wheeler BJ, Jefferies C, MacKenzie K, Hofman P, Carter P, King RI, Krausz C, van Ravenswaaij-Arts CM, Looijenga L, Drop S, Riedl S, Cools M, Dawson A, Juniarto AZ, Khadilkar V, Khadilkar A, Bhatia V, Dung VC, Atta I, Raza J, Thi Diem CN, Hao TK, Harley V, Koopman P, Warne G, Faradz S, Oshlack A, Ayers KL, Sinclair AH: Disorders of sex development: insights from targeted gene sequencing of a large international patient cohort. Genome Biol 17:243 (2016).

El-Gohary MA: Laparoscopic management of persistent mullerian duct syndrome. Pediatr Surg Int 19:533-536 (2003).

Elias-Assad G, Elias M, Kanety H, Pressman A, Tenenbaum-Rakover Y: Persistent Mullerian duct syndrome caused by a novel mutation of an anti-Mullerian hormone receptor gene: case presentation and literature review. Pediatr Endocrinol Rev 13:731-740 (2016).

Farag TI: Familial persistent Müllerian duct syndrome in Kuwait and neighboring populations. Amer J Med Genet 47:432-434 (1993).

Farikullah J, Ehtisham S, Nappo S, Patel L, Hennayake S: Persistent Mullerian duct syndrome: lessons learned from managing a series of eight patients over a 10-year period and review of literature regarding malignant risk from the Mullerian remnants. BJU Int 110:E1084-E1089 (2012).

Giri SK, Berney D, O'Driscoll J, Drumm J, Flood HD, Gupta RK: Choriocarcinoma with teratoma arising from an intra-abdominal testis in patient with persistent Mullerian duct syndrome. Lancet Oncol 5:451-452 (2004).

Glenister .0TW:The development of the utricle and so-called "middle" or "median" lobe of the human prostate. J Anat 96:443-455 (1962).

Goder V, Spiess M: Topogenesis of membrane proteins : determinants and dynamics. FEBS Letters 504:87-93 (2001).

Golladay ES, Redman JF: Transverse testicular ectopia. Urology 19:181-186 (1982).

Goto D, Aoki K, Otsuka K, Kuwada M, Yoshida K, Fujimoto K, Hirao Y: [A case of persistent Mullerian duct syndrome diagnosed by laparoscopic examination for impalpable testis]. Hinyokika Kiyo 58:507-509 (2012).

Gricourt S, Treton D, Renard-Pennat R, Samuel LJ, Bitker MO, Bichet JC, Picard JY, Touraine P: Novel AntiMullerian Hormone (AMH) mutation revealed by haematospermia in a 60 year's old patient. Clin Endocrinol (Oxf) 74:404-405 (2010).

Grinspon RP, Bedecarras P, Ballerini MG, Iniguez G, Rocha A, Mantovani Rodrigues Resende EA, Brito VN, Milani C, Figueroa G, V, Chiesa A, Keselman A, Gottlieb S, Borges MF, Ropelato MG, Picard JY, Codner E, Rey RA: Early onset of primary hypogonadism revealed by serum anti-Mullerian hormone determination during infancy and childhood in trisomy 21. Int J Androl 34:e487-e498 (2011).

Guell-Gonzalez R, Paramio-Ruibal A, Delgado-Morales B: Male pseudohermaphroditism with internal bisexual genitals. A report of two brothers. Rev RoumEndocrinol 7:343-347 (1970).

Hamby SE, Thomas NS, Cooper DN, Chuzhanova N: A meta-analysis of single base-pair substitutions in translational termination codons ('nonstop' mutations) that cause human inherited disease. Hum Genomics 5:241-264 (2011). 
Hoshiya M, Christian BP, Cromie WJ, Kim H, Zhan Y, MacLaughlin DT, Donahoe PK: Persistent Müllerian duct syndrome caused by both a 27-bp deletion and a novel splice mutation in the MIS type II receptor gene. Birth Defects Res Pt A 67:868-874 (2003).

Hutson JM, Davidson PM, Reece L, Baker ML, Zhou B: Failure of gubernacular development in the persistent Müllerian duct syndrome allows herniation of the testes. Pediatr Surg Int 9:544-546 (1994).

Imbeaud S, Belville C, Messika-Zeitoun L, Rey R, di Clemente N, Josso N, Picard JY: A 27 base-pair deletion of the anti-Müllerian type II receptor gene is the most common cause of the persistent Müllerian duct syndrome. Hum Molec Genet 5:1269-1279 (1996).

Imbeaud S, Carré-Eusèbe D, Rey R, Belville C, Josso N, Picard JY: Molecular genetics of the persistent Müllerian duct syndrome : a study of 19 families. Hum Molec Genet 3:125-131 (1994).

Imbeaud S, Faure E, Lamarre I, Mattei MG, di Clemente N, Tizard R, Carré-Eusèbe D, Belville C, Tragethon L, Tonkin C, Nelson J, McAuliffe M, Bidart JM, Lababidi A, Josso N, Cate RL, Picard JY: Insensitivity to antiMüllerian hormone due to a spontaneous mutation in the human anti-Müllerian hormone receptor. Nat Genet 11:382-388 (1995a).

Imbeaud S, Rey R, Berta P, Chaussain JL, Wit JM, Lustig RH, De Vroede MAM, Picard JY, Josso N: Progressive testicular degeneration in the persistent Müllerian duct syndrome. Eur J Pediatr 154:187-190 (1995b).

Inuganti RV, Bala GS, Kumar YK, Bharathi YK: Persistent Mullerian duct syndrome with testicular seminoma: A report of two cases. Indian J Urol 27:407-409 (2011).

Jaka RC, Shankar M: Hernia uterine inguinale with transverse testicular ectopia and mixed germ cell tumor. Indian J Urol 23:75-76 (2007).

Jinda W, Poungvarin N, Taylor TD, Suzuki Y, Thongnoppakhun W, Limwongse C, Lertrit P, Suriyaphol P, Atchaneeyasakul LO: A novel start codon mutation of the MERTK gene in a patient with retinitis pigmentosa. Mol Vis 22:342-351 (2016).

Jordan M: Ein Fall von einseitigem Descensus testiculorum. Beitr Klin Chirurg 15:245 (1895).

Jost A: Problems of fetal endocrinology : the gonadal and hypophyseal hormones. Rec Progr Horm Res 8:379418 (1953).

Kaore A, Kaore B: Persistent Müllerian duct syndrome. Nat J Integr Res Med 3:153-154 (2012).

Karimi-Nejad MH, Rowshan H, Bahadori M, Karimi-Nejad R: Persistent Müllerian derivatives. Report of a fertile male with uterine hernia syndrome with two affected sibs. Clin Genet 34:400 (1988).

Kato H, Komiyama I, Maejima T, Nishizawa O: Histopathological study of the Müllerian duct remnant : clarification of disease categories and terminology. J Urol 167:133-136 (2002)

Kevenaar ME, Themmen APN, Laven JSE, Sonntag B, Lie Fong S, Uitterlinden AG, de Jong FH, Pols HAP, Simoni M, Visser JA: Anti-Müllerian hormone and anti-Müllerian hormone type II receptor polymorphisms are associated with follicular phase estradiol levels in normo-ovulatory women. Hum Reprod 22:1547-1554 (2007a).

Kevenaar ME, Themmen APN, Rivadeneira F, Uitterlinden AG, Laven JSE, van Schoor NM, Lips P, Pols HAP, Visser JA: A polymorphism in the AMH type II receptor gene is associated with age at menopause in interaction with parity. Hum Reprod 22:2382-2388 (2007b).

Klosowski S, Abriak A, Morisot C, Bayart HC, Belville C, Thelliez P, Gottrand F, Croquette MF, Deroubaix P: Atrésie jéjunale et syndrome de persistance des canaux de mülleriens. Arch Pédiatr 4:1264-1265 (1997). 
Knebelmann B, Guerrier D, Legeai L, Kahn A, Josso N, Picard JY: A nonsense mutation in the last exon of the anti-Müllerian hormone gene is responsible for the persistent Müllerian duct syndrome in three brothers. Horm Res 33:11-12 (1990).

Kobayashi A, Stewart CA, Wang Y, Fujioka K, Thomas NC, Jamin SP, Behringer RR: beta-Catenin is essential for Mullerian duct regression during male sexual differentiation. Development 138:1967-1975 (2011).

Korkmaz O, Ozen S, Ozcan N, Bayindir P, Sen S, Onay H, Goksen D, Avanoglu A, Ozkinay F, Darcan S: Persistent Müllerian duct syndrome sith transverse testicular ectopia : a novel AMH receptor mutation. J Clin Res Pediatr Endocrinol in press (2017).

Kovachev SM, Nikolov SD, Mihova AP: Uterine leiomyoma in a man with persistent Mullerian duct syndrome and seminoma. Isr Med Assoc J 16:735-737 (2014).

Kozak M: Pushing the limits of the scanning mechanism for initiation of translation. Gene 299:1-34 (2002).

Kumar S, Mohan A: Persistent Mullerian duct syndrome with transverse testicular ectopia. J Surg Case Rep 2012:9 (2012).

Lasala C, Schteingart HF, Arouche N, Bedecarras P, Grinspon RP, Picard JY, Josso N, di Clemente N, Rey R: SOX9 and SF1 are involved in cyclic AMP-mediated upregulation of anti-Mullerian gene expression in the testicular prepubertal Sertoli cells SMAT1. Am J Physiol Endocrinol Metab 301:E539-E547 (2011).

Liang YY, Zheng FF, Dai YP, Zheng KL, Zhou JX: Persistent Muellerian duct syndrome with transverse testicular ectopia. Asian J Androl 8:745-747 (2006).

Lindgren G : Pubertal changes 1980 of Stockholm schoolchildren. Acta Paediatr 85:1365-1367

Loeff DS, Imbeaud S, Reyes HM, Meller JL, Rosenthal IM: Surgical and genetic aspects of persistent Müllerian duct syndrome. J Pediatr Surg 29:61-65 (1994).

Manassero F, Cuttano MG, Morelli G, Salinitri G, Spurio M, Selli C: Mixed germ cell tumor after bilateral orchidopexy in persistent Mullerian duct syndrome with transverse testicular ectopia. Urol Int 73:81-83 (2004).

Manjunath BG, Shenoy VG, Raj P: Persistent mullerian duct syndrome: How to deal with the mullerian duct remnants - a review. Indian J Surg 72:16-19 (2010).

Matzuk MM, Finegold MJ, Mishina Y, Bradley A, Behringer RR: Synergistic effects of inhibins and Mullerianinhibiting substance on testicular tumorigenesis. Mol Endocrinol 9:1337-1345 (1995).

Mazen I, Abdel Hamid MS, El-Gammal M, Aref A, Amr K: AMH gene mutations in two Egyptian families with Persistent Mullerian Duct Syndrome. Sex Dev 11:29-33 (2011).

Mazen I, Elgammal M, McElreavey K, Abdelhamed M, Elaydi A: Novel AMH and AMHRII mutations in two Egyptian families with persistent Müllerian duct syndrome (abstr.). 55th Annual Meeting of the European Society of Paediatric Endocrinology (ESPE). Horm Res Paediatr 82:255 (2016).

Melman A, Leiter E, Perez JM, Driscoll D, Palmer C: The influence of neonatal orchiopexy upon the testis in persistent Mullerian duct syndrome. J Urol 125:856-858 (1981).

Mentrup B, Marschall C, Barvencik F, Amling M, Plendl H, Jakob F, Beck C: Functional characterization of a novel mutation localized in the start codon of the tissue-nonspecific alkaline phosphatase gene. Bone 48:1401-1408 (2011).

Merkel JS, Regan L: Aromatic rescue of glycine in beta sheets. Fold Des 3:449-455 (1998). 
Messika-Zeitoun L, Gouédard L, Belville C, Dutertre M, Lins L, Imbeaud S, Hughes IA, Picard JY, Josso N, di Clemente $\mathrm{N}$ : Autosomal recessive segregation of a truncating mutation of anti-Müllerian hormone type II receptor in a family affected by the persistent Müllerian duct syndrome contrasts with its dominant negative activity in vitro. J Clin Endocrinol Metab 86:4390-4397 (2001).

Meyers-Wallen VN, Donahoe PK, Ueno S, Manganaro TF, Patterson DF: Müllerian inhibiting substance is present in testes of dogs with persistent mullerian duct syndrome. Biol Reprod 41:881-888 (1989).

Mi LZ, Brown CT, Gao Y, Tian Y, Le VQ, Walz T, Springer TA: Structure of bone morphogenetic protein 9 procomplex. Proc Natl Acad Sci U S A 112:3710-3715 (2015).

Miller A, Hong MK, Hutson JM: The broad ligament: a review of its anatomy and development in different species and hormonal environments. Clin Anat 17:244-251 (2004).

Mishina Y, Whitworth DJ, Racine C, Behringer RR: High specificity of Müllerian-inhibiting substance signaling in vivo. Endocrinology 140:2084-2088 (1999).

Modi J, Modi D, Bachani L: Acute urinary retention caused by seminoma in a case of persistent Mullerian duct syndrome. Indian J Pathol Microbiol 58:83-85 (2015).

Mohapatra M, Subramanya YS: Persistent Müllerian duct syndrome of mixed anatomical variant (combined male and female type) with mixed germ cell tumor of left intra-abdominal testis. Indian J Pathol Microbiol 59:212-215 (2016).

Mollaeian M, Mehrabi V, Elahi B: Significance of epididymal and ductal anomalies associated with undescended testis: study in 652 cases. Urology 43:857-860 (1994).

Morikawa S, Moriya K, Ishizu K, Tajima T: Two heterozygous mutations of the AMH gene in a Japanese patient with persistent Mullerian duct syndrome. J Pediatr Endocrinol Metab 27:1223-1226 (2014).

Morillo-Cucci G, German J: Males with a uterus and fallopian tubes, a rare disorder of sexual development. Birth Defects Orig Artic Ser 7:229-231 (1971).

Mouli D, McCarthy P, Ray P, Ray V, Rosenthal IM: Persistent Müllerian duct syndrome in a man with transverse testicular ectopia. J Urol 139:373-375 (1988).

Mullen RD, Behringer RR: Molecular genetics of Mullerian duct formation, regression and differentiation. Sex Dev 2014).

Naguib KK, Teebi AS, Al Awadi SA, El Khalifa MY, Mahfouz ES: Familial uterine hernia syndrome : report of an Arab family with four affected males. Amer J Hum Genet 33:180-181 (1989).

Nalbantoglu O, Demir K, Korkmaz HA, Buyukinan M, Yildiz M, Tunc S, Ozkan B: A novel mutation of AMH in three siblings with persistent Mullerian duct syndrome. J Pediatr Endocrinol Metab 28:1379:1382 (2015).

Nelson SM, Pastuszek E, Kloss G, Malinowska I, Liss J, Lukaszuk A, Plociennik L, Lukaszuk K: Two new automated, compared with two enzyme-linked immunosorbent, antimullerian hormone assays. Fertil Steril 104:1016-1021 (2015).

Nickel RF, Ubbink G, van der Gaag, I, van Sluijs FJ: Persistent mullerian duct syndrome in the basset hound. Tijdschr Diergeneeskd 117 Suppl 1:31S (1992).

Nilson O: Hernia uteri inguinalis beim Manne. Acta Chir Scand 83:231 (1939).

Nishi MY, Domenice S, Maciel-Guerra AT, Zaba NA, Silva MA, Costa EM, Guerra-Junior G, Mendonca BB: Analysis of anti-Mullerian hormone $(A M H)$ and its receptor (AMHR2) genes in patients with persistent Mullerian duct syndrome. Arq Bras Endocrinol Metabol 56:473-478 (2012). 
Orvis GD, Jamin SP, Kwan KM, Mishina Y, Kaartinen VM, Huang S, Roberts AB, Umans L, Huylebroeck D, Zwijsen A, Wang D, Martin JF, Behringer RR: Functional redundancy of TGF-beta family type receptors and receptorsmads in mediating anti-Mullerian hormone-induced Mullerian duct regression in the mouse. Biol Reprod 78:994-1001 (2008).

Panasiewicz G, Zamojska A, Bieniek M, Gizejewski Z, Szafranska B: Persistent Mullerian duct syndrome (PMDS) in the Polish free-ranged bull populations of the European bison (Bison bonasus L.). Anim Reprod Sci 152:123136 (2015).

Parr BA, McMahon AP: Sexually dimorphic development of the mammalian reproductive tract requires Wnt-7a. Nature 395:707-710 (1998).

Parrini C, Taddei N, Ramazzotti M, Degl'Innocenti D, Ramponi G, Dobson CM, Chiti F: Glycine residues appear to be evolutionarily conserved for their ability to inhibit aggregation. Structure 13:1143-1151 (2005).

Pepinsky RB, Sinclair LK, Chow EP, Mattaliano RJ, Manganaro TF, Donahoe PK, Cate RL: Proteolytic processing of Müllerian inhibiting substance produces a transforming growth factor-?-like fragment. J Biol Chem 263:1896118965 (1988).

Picard JY, Benarous R, Guerrier D, Josso N, Kahn A: Cloning and expression of cDNA for anti-Müllerian hormone. Proc Natl Acad Sci (USA) 83:5464-5468 (1986).

Pierre A, Racine C, Rey RA, Fanchin R, Taieb J, Cohen-Tannoudji J, Carmillo P, Pepinsky RB, Cate RL, di Clemente $\mathrm{N}$ : Most cleaved anti-Mullerian hormone binds its receptor in human follicular fluid but little is competent in serum. J Clin Endocrinol Metab 101:4618-4627 (2016).

Prakash N, Khurana A, Narula B: Persistent Mullerian duct syndrome. Indian J Pathol Microbiol 52:546-548 (2009).

Pujar S, Meyers-Wallen VN: A molecular diagnostic test for persistent Mullerian duct syndrome in miniature schnauzer dogs. Sex Dev 3:326-328 (2009).

Romero FR, Fucs M, Castro MG, Garcia CR, Fernandes RC, Perez MD: Adenocarcinoma of persistent mullerian duct remnants: case report and differential diagnosis. Urology 66:194-195 (2005).

Rosal-Gonçalves M, Almeida C, Barber J, Kay T, Limbert C, Lopes L, Fonseca G: Mutation of the MIF type II receptor in two brothers. J Pediatr Endocrinol Metab 23:315-317 (2010).

Royer P, Pellerin D, Habib R, Vermeil G, Rodriguez-Soriano J: Le pseudohermaphrodisme masculin interne à organes génitaux externes masculins normaux. Ann Pédiatr 37:143-149 (1961).

Sargiannidou I, Kim GH, Kyriakoudi S, Eun BL, Kleopa KA: A start codon CMT1X mutation associated with transient encephalomyelitis causes complete loss of Cx32. Neurogenetics 16:193-200 (2015).

Scrivere E, Montali E, Forti G: Familial male internal pseudohermaphroditism; report on a case. Horm Res 7:280-287 (1976).

Shamim M: Persistent Mullerian duct syndrome with transverse testicular ectopia presenting in an irreducible recurrent inguinal hernia. J Pak Med Assoc 57:421-423 (2007).

Sharma S, Sen A: Complete testicular epididymal dissociation in the abdominal cryptorchid testis. J Pediatr Urol 9:1023-1027 (2013).

Shen WH, Moore CCD, Ikeda Y, Parker KL, Ingraham HA: Nuclear receptor steroidogenic factor 1 regulates the mullerian inhibiting substance gene: A link to the sex determination cascade. Cell 77:651-661 (1994). 
Sherwani AY, Shah AQ, Wani AM, Bashir AC, Bashir AK, Sofi FA, Wani AA, Lone W, Sherwani AH, Sheikh MR, Sharma RR: Hysterectomy in a male? A rare case report. Int J Surg Case Rep 5:1285-1287 (2014).

Sichani M.M., Heidarpour M, Dadkhah A, Rezvani M: Persistent mullerian duct syndrome with an irreducible inguinal hernia. Urol J 6:298-300 (2009).

Sloan WR, Walsh PC: Familial persistent Müllerian duct syndrome. J Urol 115:459-461 (1976).

Smith-Harrison LI, Patel MS, Smith RP, Schenkman NS: Persistent Mullerian duct structures presenting as hematuria in an adult: Case report of robotic surgical removal and review of the literature. Urol Ann 7:544-546 (2015).

Snow BW, Rowland RG, Seal GM, Williams SD: Testicular tumor in patient with persistent mullerian duct syndrome. Urology 26:495-497 (1985).

Souto CAV, Oliveira MD, Teloken C, Paskulin G, Hoffmann K: Persistence of Mullerian duct derivative syndrome in 2 male patients with bilateral cryptorchidism. J Urol 153:1637-1638 (1995).

Tanwar PS, Commandeur AE, Zhang L, Taketo MM, Teixeira JM: The Mullerian inhibiting substance type 2 receptor suppresses tumorigenesis in testes with sustained beta-catenin signaling. Carcinogenesis 33:23512361 (2012).

Taylor SS, Kornev AP: Protein kinases: evolution of dynamic regulatory proteins. Trends Biochem Sci 36:65-77 (2011).

Thiel DD, Erhard MJ: Uterine adenosarcoma in a boy with persistent mullerian duct syndrome: first reported case. J Pediatr Surg 40:e29-e31 (2005).

Vainio S, Heikkilä M, Kispert A, Chin N, McMahon AP: Female development in mammals is regulated by Wnt-4 signaling. Nature 397:405-409 (1999).

Valeri C, di Clemente N, Marshall I, Scheingart H, Josso N, Rey R, Picard JY: 46,XY DSD due to isolated AMH deficiency resulting in persistent Müllerian duct syndrome as a consequence of a single base deletion in a SF-1 Response Element of the AMH promoter (abstr.). 55th Annual Meeting of the European Society of Paediatric Endocrinology (ESPE). Horm Res Paediatr 82:521 (2016).

van der Zwan YG, Bruggenwirth HT, Drop SL, Wolffenbuttel KP, Madern GC, Looijenga LH, Visser JA: A novel AMH missense mutation in a patient with Persistent Mullerian Duct Syndrome. Sex Dev 6:279-283 (2012).

van Maldergem L, Bachy A, Feldman D, Bouillon R, Maassen J, Dreyer M, Rey R, Holm C, Gillerot Y: A syndrome exhibiting lipoatrophic diabetes, vitamin $D$ resistant rickets, and persistent Müllerian ducts in a Turkish boy born to consanguineous parents. Amer J Med Genet 64:506-513 (1996).

Vandersteen DR, Chaumeton AK, Ireland K, Tank ES: Surgical management of persistent müllerian duct syndrome. Urology 49:941-945 (1997).

van Haelst MM, Hoogeboom J, Galjaard RJH, Kleijer WJ, den Hollander NS, de Krijger RR, Hennekam RCM, Niermeijer MF: Lymphangiectasia with persistent Müllerian derivatives: Confirmation of autosomal recessive Urioste syndrome. Amer J Med Genet 104:65-68 (2001).

Watanabe K, Clarke TR, Lane AH, Wang XZ, Donahoe PK: Endogenous expression of Müllerian inhibiting substance in early postnatal rat Sertoli cells requires multiple steroidogenic factor-1 and GATA-4- binding sites. Proc Natl Acad Sci USA 97:1624-1629 (2000).

Webster J: A rare case of hermaphroditism. Surgery, Gynecology and Obstetrics 3:484 (1906). 
Williams JC, Merguerian PA, Schned AR, Amdur RJ: Bilateral testicular carcinoma in situ in persistent mullerian duct syndrome: a case report and literature review. Urology 44:595-598 (1994).

Wu XF, Wan SQ, Pujar S, Haskins ME, Schlafer DH, Lee MM, Meyers-Wallen VN: A single base pair mutation encoding a premature stop codon in the MIS type II receptor is responsible for canine Persistent Mullerian Duct Syndrome. J Androl 30:46-56 (2009).

Yang J, Wu J, Steichen JM, Kornev AP, Deal MS, Li S, Sankaran B, Woods VL, Jr., Taylor SS: A conserved Glu-Arg salt bridge connects coevolved motifs that define the eukaryotic protein kinase fold. J Mol Biol 415:666-679 (2012).

Zeller J, Imbeaud S, Rey R, Adamsbaum C, Fourmaintraux A, Donnet JP, van Kote G, Josso N, Chaussain JL: Le syndrome de persistance des dérivés mülleriens (hommes à utérus) : un problème pédiatrique. Arch Pédiatr 1:991-997 (1994).

Zhapa E, Castagnetti M, Alaggio R, Talenti E, Rigamonti W: Testicular fusion in a patient with transverse testicular ectopia and persistent mullerian duct syndrome. Urology 76:62-64 (2010). 


\section{Legend of figures}

Figure 1: The three main clinical presentations of persistent Müllerian duct syndrome. A) Bilateral cryptorchidism: the testes are in the pelvis, in the position of normal ovaries. This presentation is found in approximately $55 \%$ of cases with mutations in the $\mathrm{AMH}$ pathway and in $86 \%$ of idiopathic cases. B) Unilateral cryptorchidism: one testis is in an inguinal hernia along with its attached tube and uterus. This presentation is known as 'hernia uteri inguinalis' and occurs in approximately $20 \%$ of cases with mutations of the AMH pathway and in $14 \%$ of idiopathic cases. C) Transverse testicular ectopia: both testes and part of the Müllerian organs have herniated into a single processus vaginalis. This presentation is very evocative of PMDS and is seen in approximately $25 \%$ of cases with $\mathrm{AMH}$ or AMHRII mutations but never in idiopathic cases $(p<0.001)$. Permission obtained from Nature Publishing group Hutson JM et al Malformation syndromes associated with disorders of sexual development Nat. Rev. Endocrinol. 10, 476-487 (2014).

Figure 2: Position of the testes in PMDS patients with or without detectable mutations in the AMH pathway. Relevant data were available in 151 patients; the number in each category is indicated at the top of the bar.

Figure 3: Operative findings in a patient with a mutation of the $\mathrm{AMH}$ receptor, showing the adherence of the testes to the Fallopian tubes. Before surgery, this patient had transverse testicular ectopia. Reprinted with permission from Abduljabbar M, Taheini K, Picard JY, Cate RL and Josso, N Mutations of the AMH Type II receptor in two extended families with persistent Müllerian duct syndrome: lack of phenotype/genotype correlation Horm. Res. Paed. 77:291-297 2012

Figure 4: Homozygosity in PMDS patients in various parts of the world. AF: Africa (12 out of 17 patients are from Maghreb); AM: America (mostly South America); NE: Northern Europe (including France North of the Loire) SE: Southern Europe (including France South of the Loire); ME: Greater Middle East according to Wikipedia. The number of patients is indicated at the top of the bar.

Figure 5: $\mathrm{AMH}$ processing. Full length homodimeric $\mathrm{AMH}$ is cleaved at arginine 451 into a long $\mathrm{N}$-terminal fragment and an short C-terminal fragment, carrying the biological activity The two fragments are associated in a non-covalent complex which is able to interact with the receptor. Separation of the $\mathrm{C}$ and $\mathrm{N}$ terminal fragments occurs only after binding to the receptor. Reprinted with permission from di Clemente N, Jamin SP, Lugovskoy A, Carmillo P, Ehrenfels C, Picard JY, Whitty A, Josso N, Pepinsky RB, Cate RL Processing of antiMüllerian Hormone regulates receptor activation by a mechanism distinct from TGF. Mol Endo 24:2193-2206

Figure 6: Recurrent mutations (red print) and those of particular interest (black print) detected in the $\mathrm{AMH}$ gene $(A)$ and the AMHRII gene (B). n: number of affected families. Type of mutation: missense, yellow box; nonsense, white box; deletion, green box; insertion, blue box; splicing mutation, star.

Figure 7: Schematic representation of the $\mathrm{AMH}$ gene $(\mathrm{A})$, and the AMHRIl gene (B). The number of total and different mutations and the number of mutations per 100 base pairs are shown for each exon. $\mathrm{N}$-terminal: coding the pro-region of the AMH protein; C-terminal: coding the mature, biologically active region of the protein. Note that the rate of mutations for 100 base pairs is much higher for the $\mathrm{C}$-terminus.

Figure 8: Molecular model of the C-terminal mature AMH dimer showing the p.(Gly533Val) mutation. To allow a comparison, one monomer is shown in green and contains the wild type residue Gly533, while the other monomer is shown in blue and contains the mutant residue Val533. Disulfide bonds which form the cysteine knot motif are shown as sticks in yellow. The residues at position 533 are shown as spheres.

Figure 9: Cross-talk between $\mathrm{AMH}$ and $\mathrm{Wnt} / \beta$-catenin pathways. Upon $\mathrm{AMH}$ binding to AMHRII, type I receptors ALK2 and ALK3 are recruited, resulting in activation of SMADS $1 / 5 / 8$, which translocate to the nucleus in concert with Smad4 to regulate the expression of target genes, including Wnt4 or $5 \mathrm{~A}$ and others. These factors stabilize $\beta$-catenin which associates with T-cell factor (TCF)/lymphocyte enhancer factor 1 (LEF1) 
to activates transcription of gene products involved in regression of the Müllerian duct epithelium (e.g. apoptosis induced by caspase-3 cleavage).

Figure 10: Detection of the 27 bp deletion in exon 10 by PCR. SM: DNA size markers. $c /$ control, F father, M mother; 1-3 phenotypically normal siblings.4 PMDS propositus; The figure shows the segregation of a normal allele (382 bp) and a smaller, deleted one (355 bp) which migrates faster. Brother 2 has 2 normal alleles represented by a single, slow migrating band. Sister 1 and the propositus are homozygous for the deleted allele, represented by a single, fast migrating band. Consanguineous parents and brother 3 are heterozygous for the mutations, as shown by the presence of both the slow and fast migrating bands. Reprinted with permission from Josso N, Cate RL, Picard JY The Persistent Müllerian Duct syndrome in Genetic Steroid Disorders, MI New, A Parsa, TT Yuen, B O'Malley, and GD Hammer, eds. (New York: Elsevier) 2013.

Figure 11: Molecular models of the kinase domain of AMHRII showing the location of the amino acids affected by the p.(Gly445_Leu453del) mutation. A) A close up view showing the amino acids affected by the deletion mutation as sticks; the residues are located in the $\alpha G$ helix and preceding loop. B) A view of the entire kinase domain showing the proximity of the $\alpha \mathrm{G}$ helix to the Activation segment (shown in magenta), two conserved features within eukaryotic protein kinases that have coevolved as part of a regulatory mechanism

Supplemental figure 1: All the mutations detected in the $\mathrm{AMH}$ gene by ourselves and others. Recurrent mutations are shown in red. Type of mutation: missense, yellow box; nonsense, white box; deletion, green box; insertion, blue box; splicing mutation, star.

Supplemental figure 2: All the mutations detected in the AMHRII gene by ourselves and others. Recurrent mutations are shown in red. Type of mutation: missense, yellow box; nonsense, white box; deletion, green box; insertion, blue box; splicing mutation, star.

Legend of Table: Normal values for serum AMH (pmol/L) in developing boys assayed with the ultrasensitive EIA Beckman-Immunotech AMH/MIS kit (reference A18893). Results according to Grinspon et al. [2011]. To obtain values in $\mathrm{ng} / \mathrm{ml}$, divide by 7.14 . The EIA kit is no longer commercially available, pediatric normograms have not been published for the kits now on sale. An international standard of measurement of AMH has yet to be defined. G1-G5: genitalia development stages according to Lindgren [1996].

Supplemental table 1: PMDS patients with AMH mutations detected by ourselves (in black) or by others (in blue). Mutations are arranged by their coding position on the gene, according to HGVS recommendations. In our previous publications, numbering was genomic from the transcription site. Recurrent mutations are boxed and specified only once. Homo: homozygous mutation, Hetero: 2 different mutations, Hemi: hemizygous with only one detected mutation. France N: North of the river Loire; S: South of the Loire.

Supplemental table 2: PMDS patients with AMHRII mutations detected in by ourselves (in black) or others (in blue). Mutations are arranged by their coding position on the gene, according to HGVS recommendations. In our previous publications, numbering was genomic from the transcription site. Recurrent mutations are boxed and specified only once. Homo: homozygous mutation, Hetero: 2 different mutations, Hemi: hemizygous with only one detected mutation. France N: North of the river Loire; S: South of the Loire. 

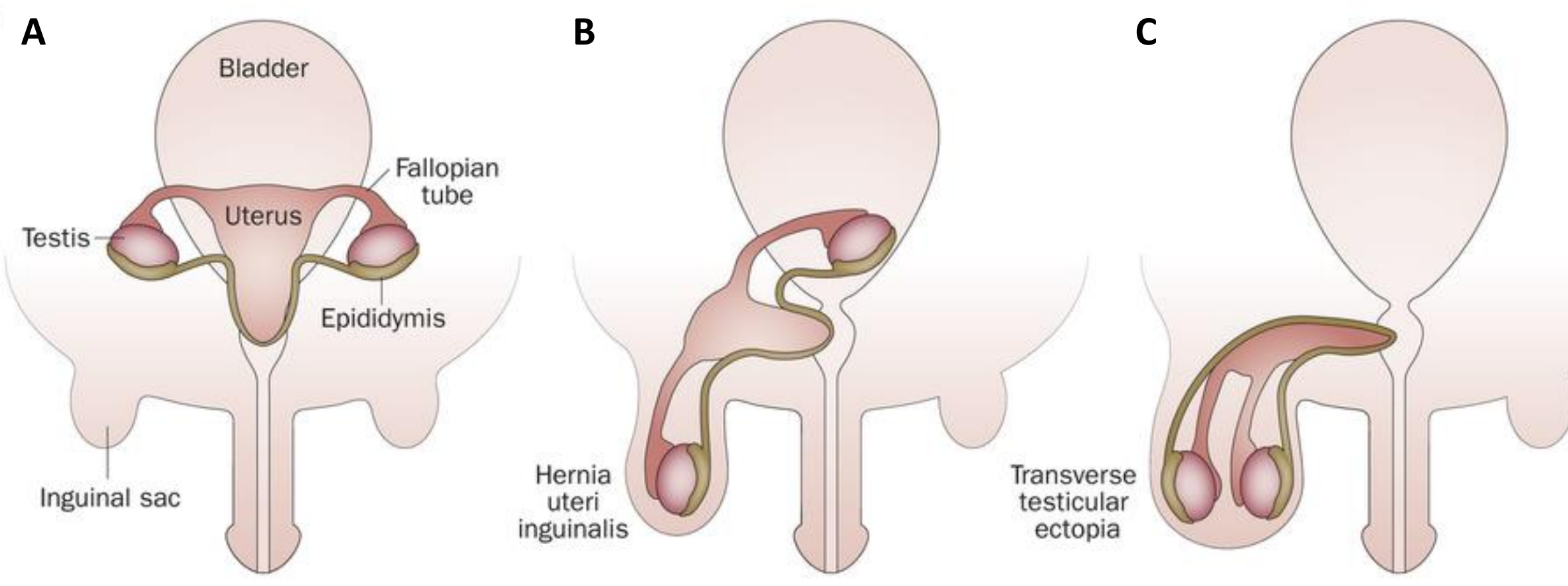

Fig. 1 


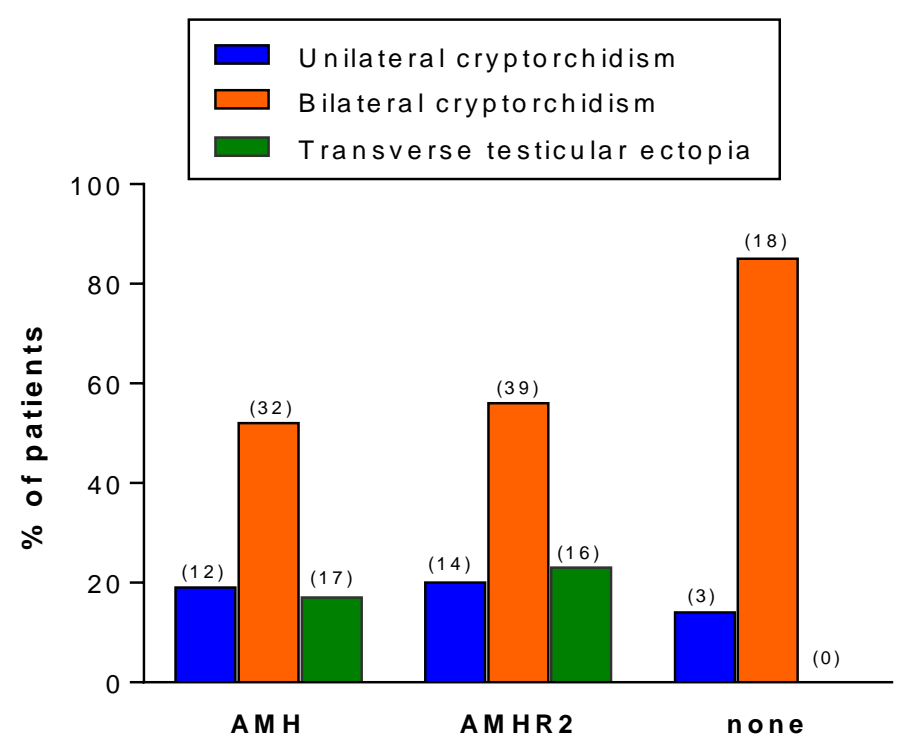

Fig. 2 


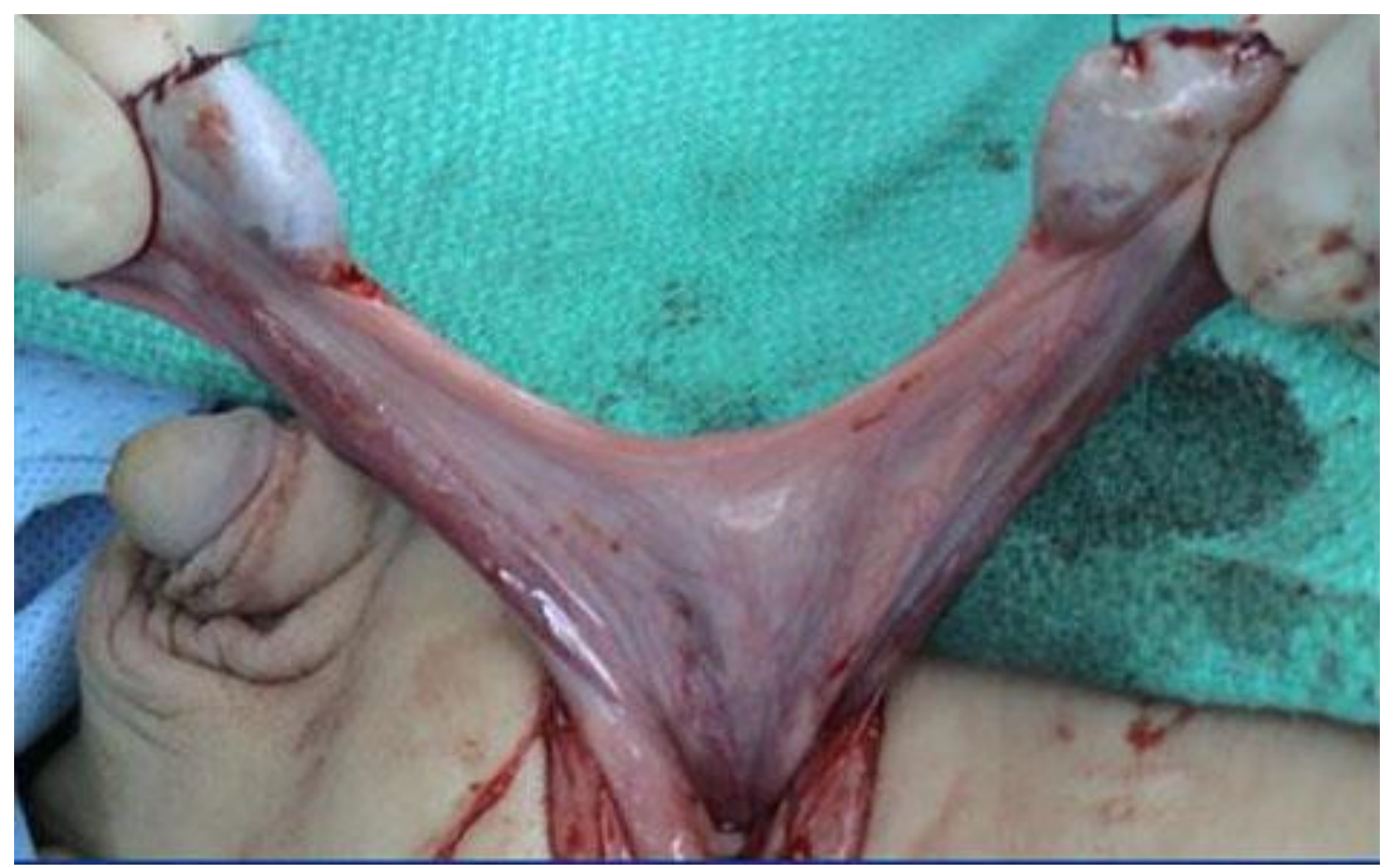

Fig. 3 


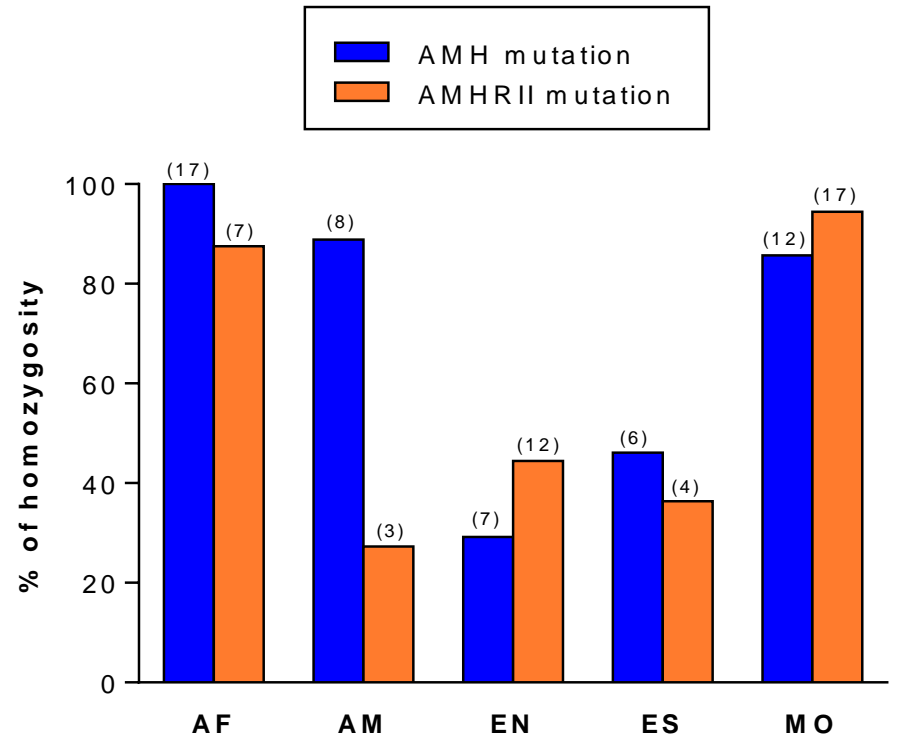

Fig. 4 


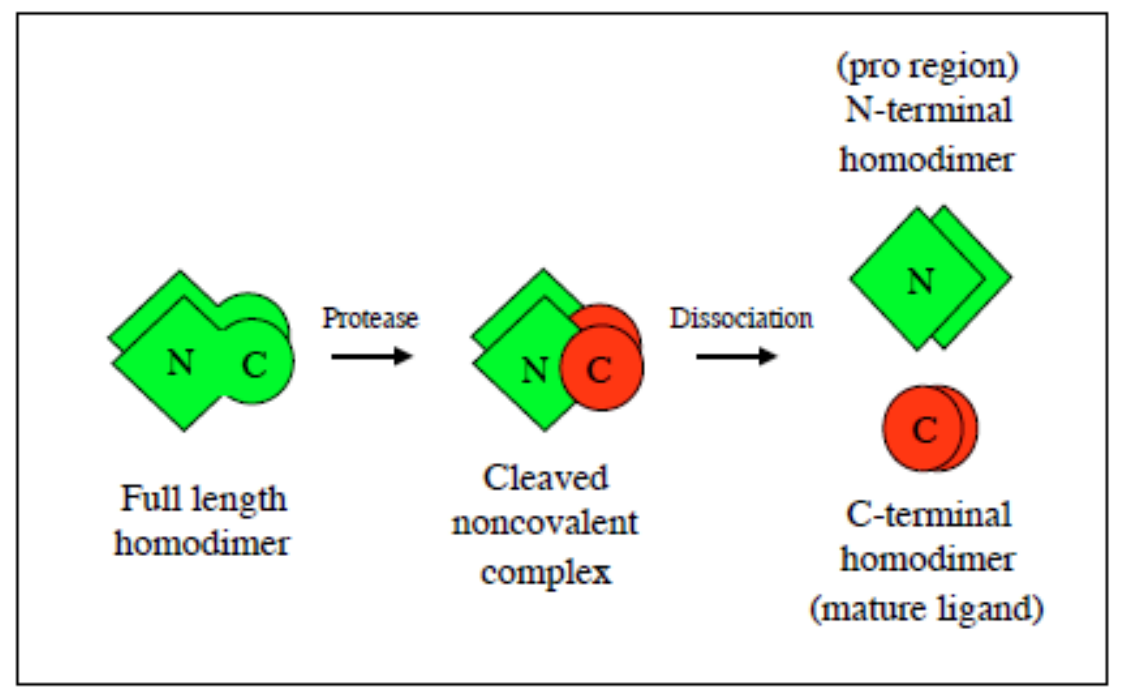

Fig. 5 

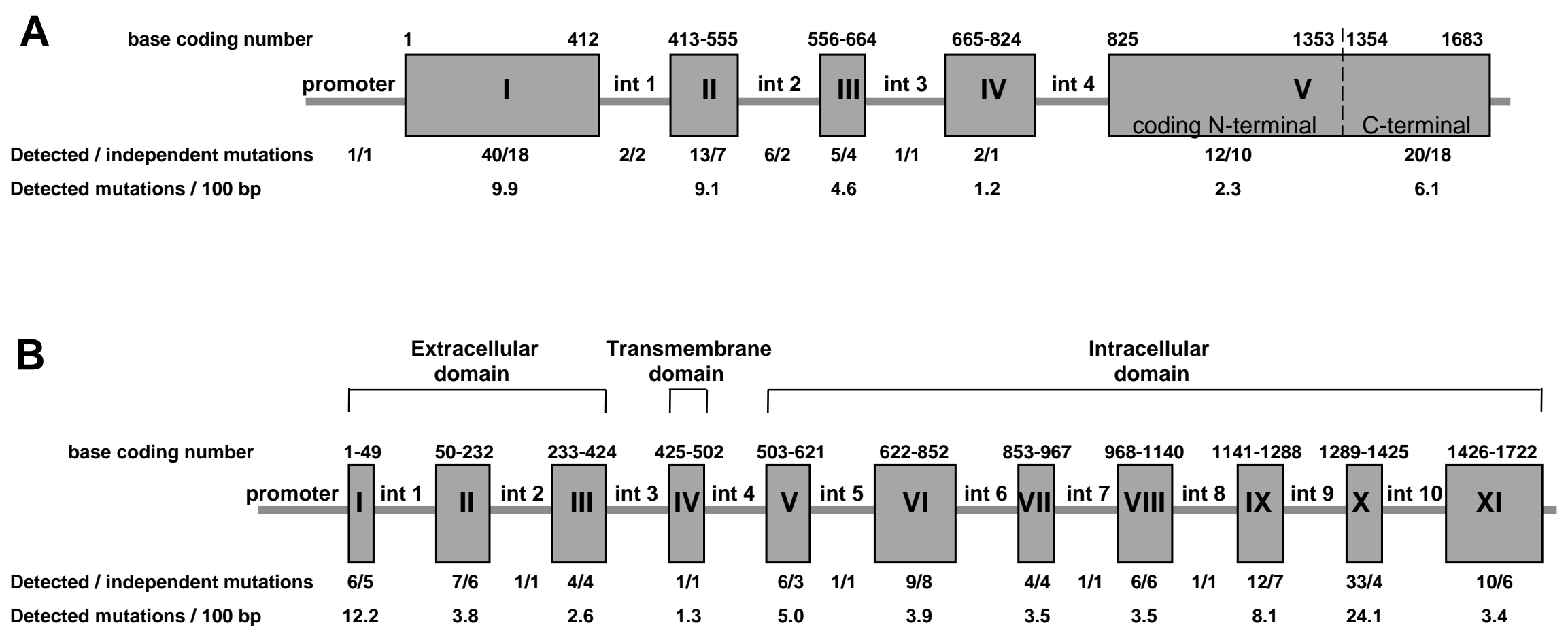

Fig. 7 


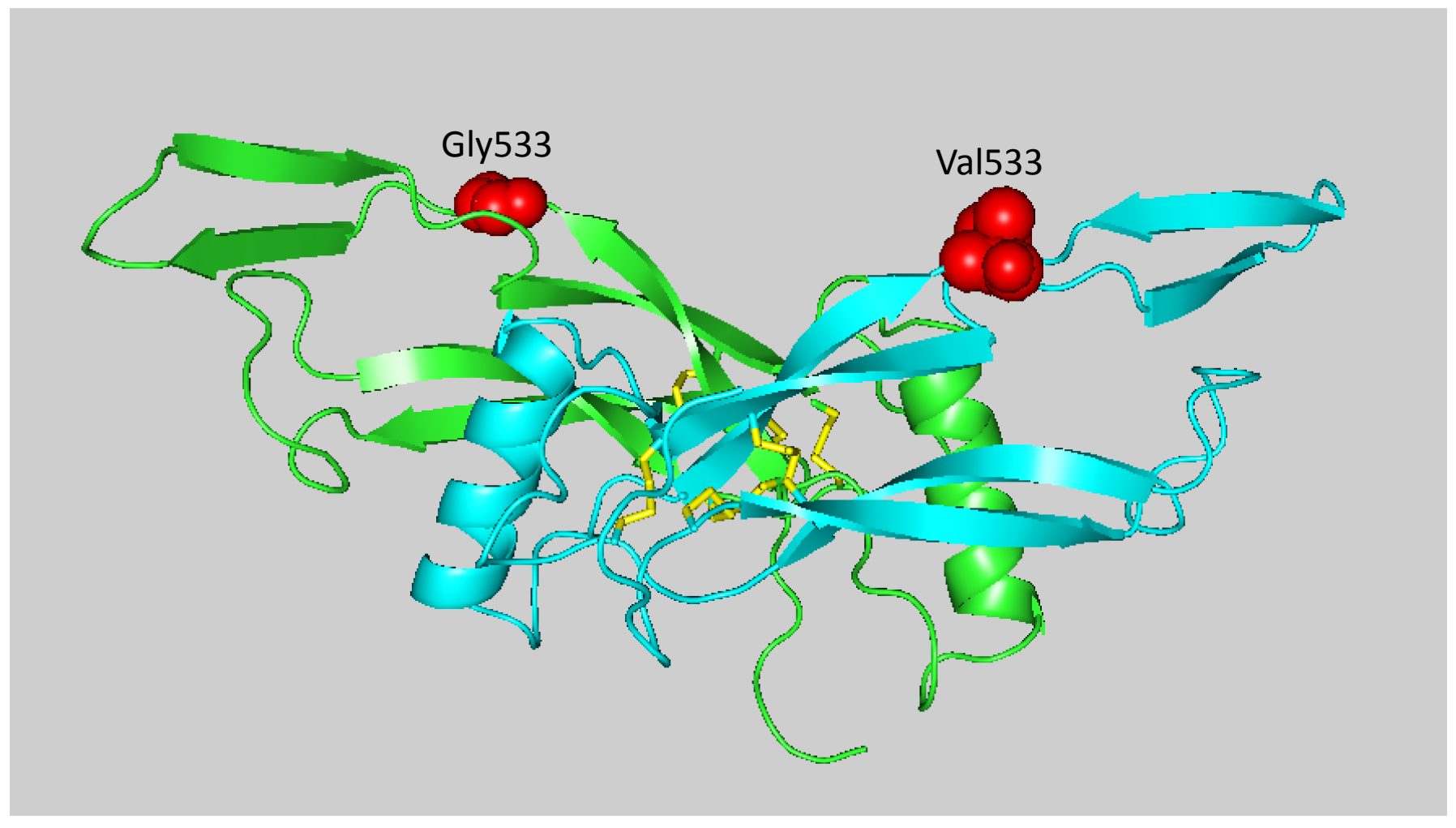

Fig. 8 


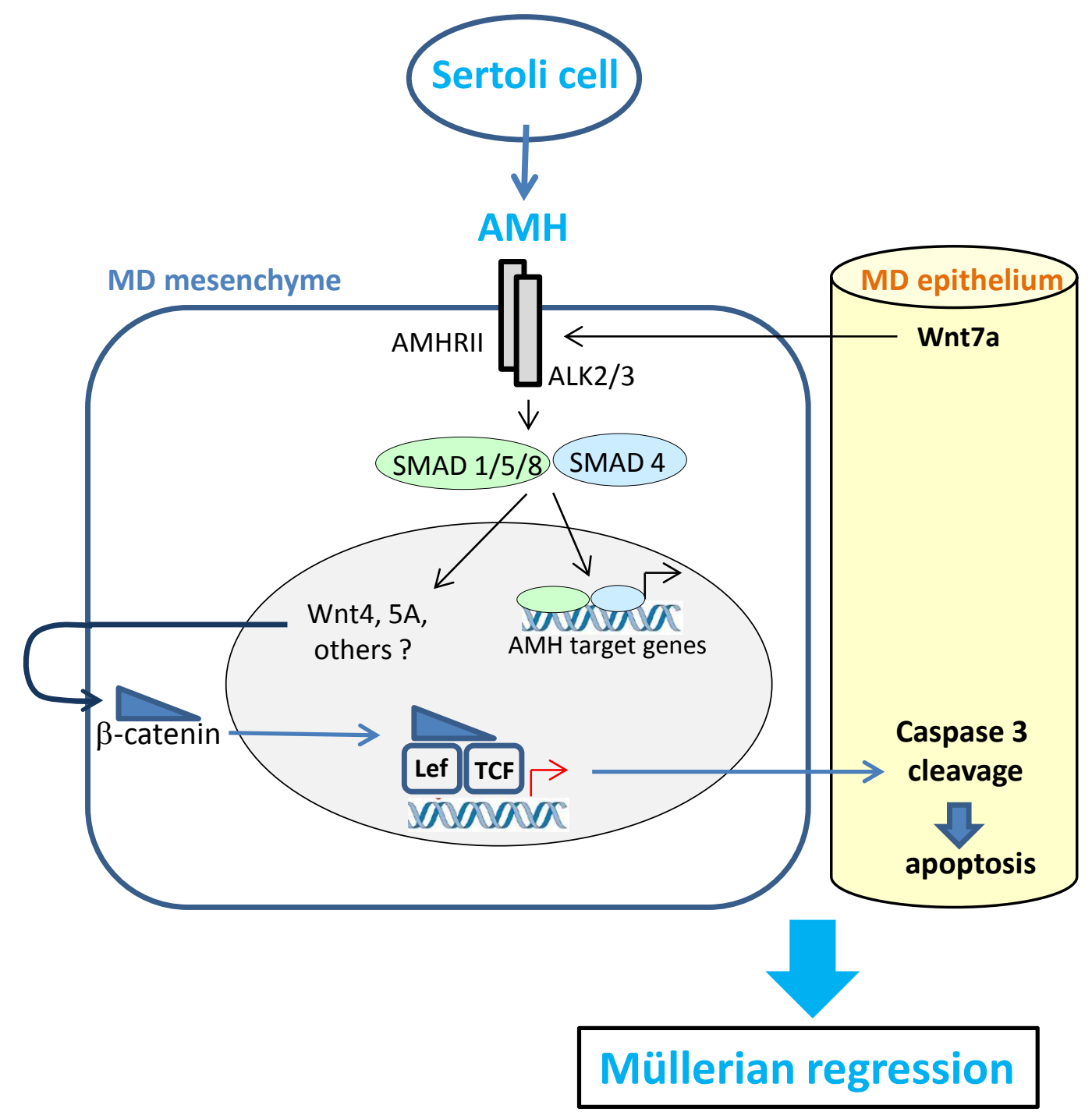

Fig. 9 


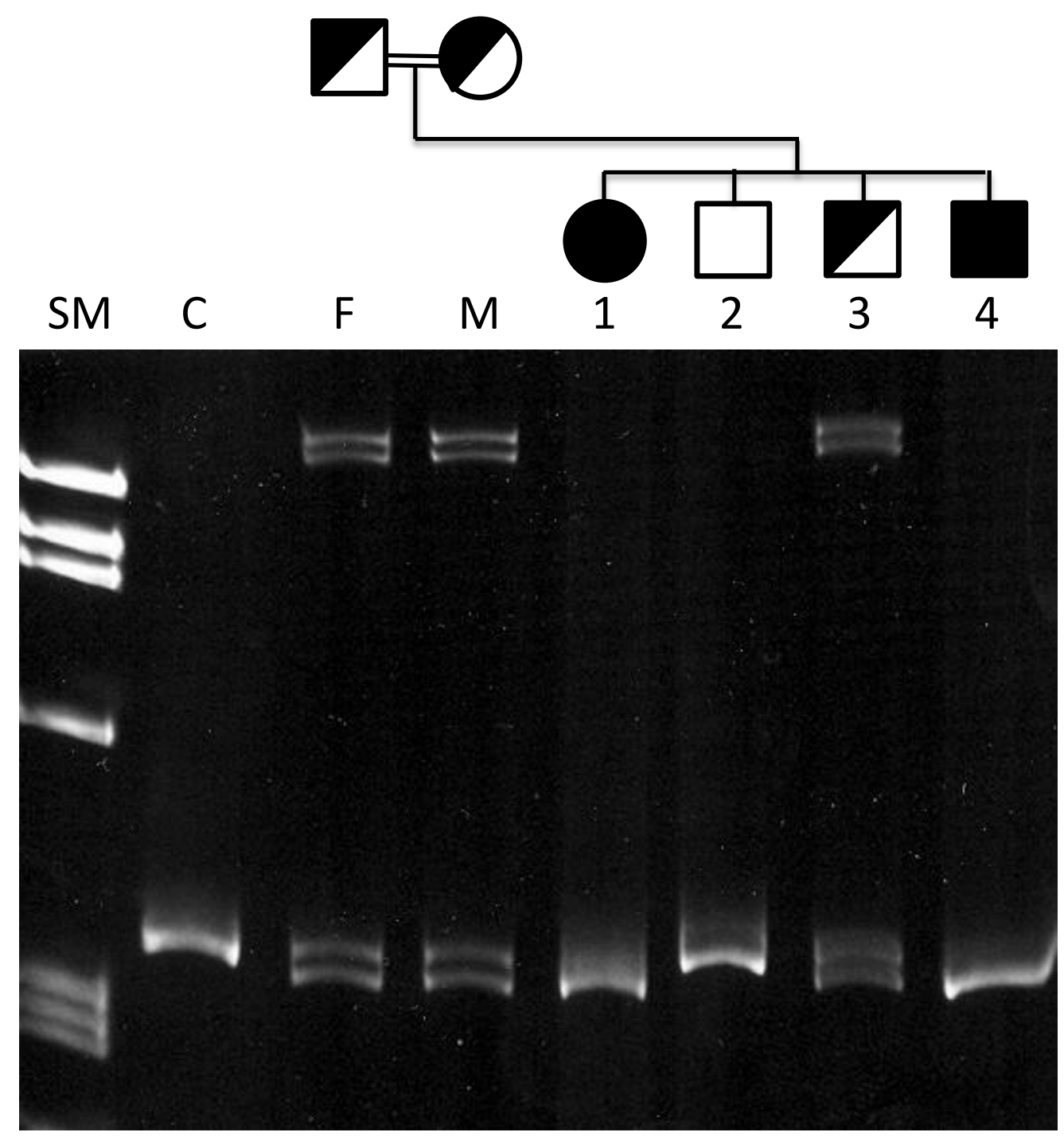

Fig. 10 


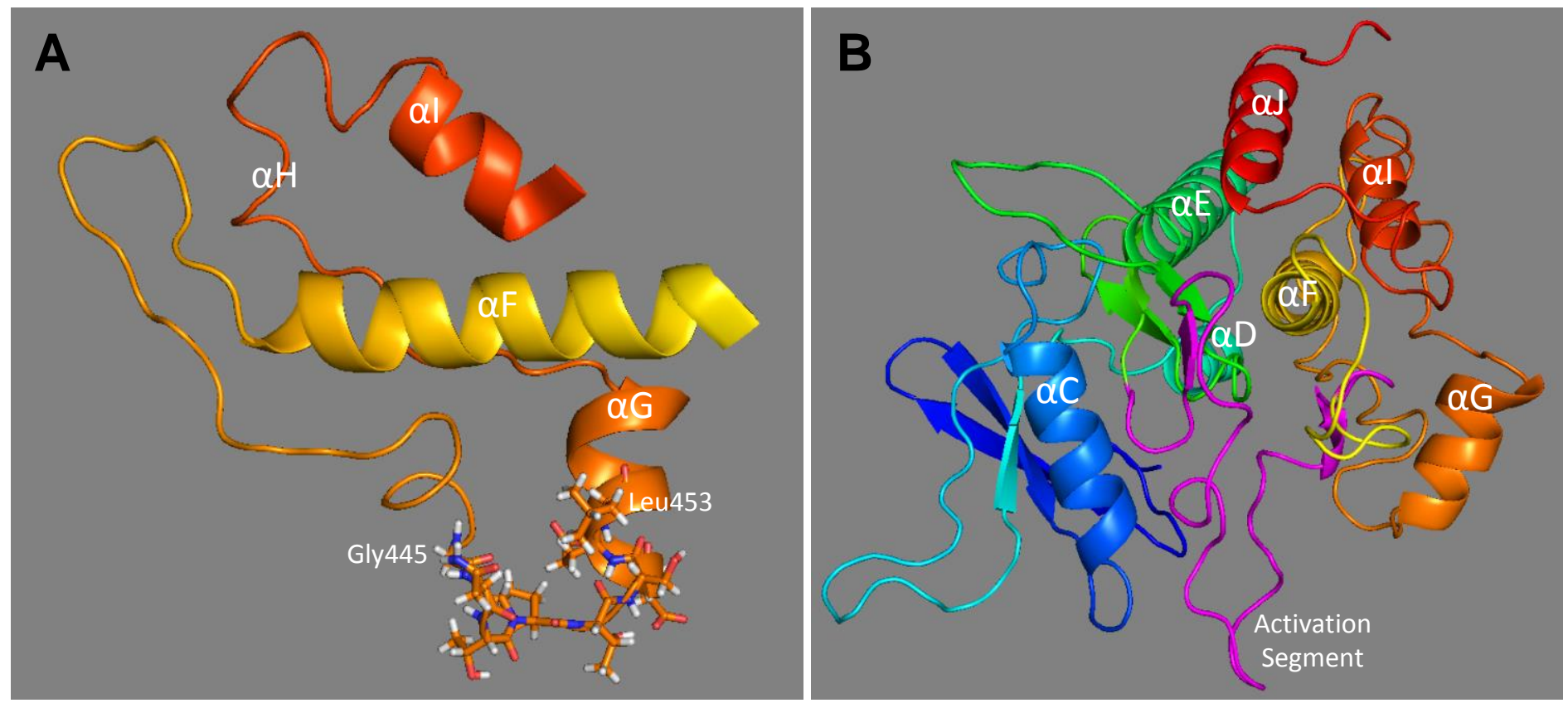

Fig. 11 


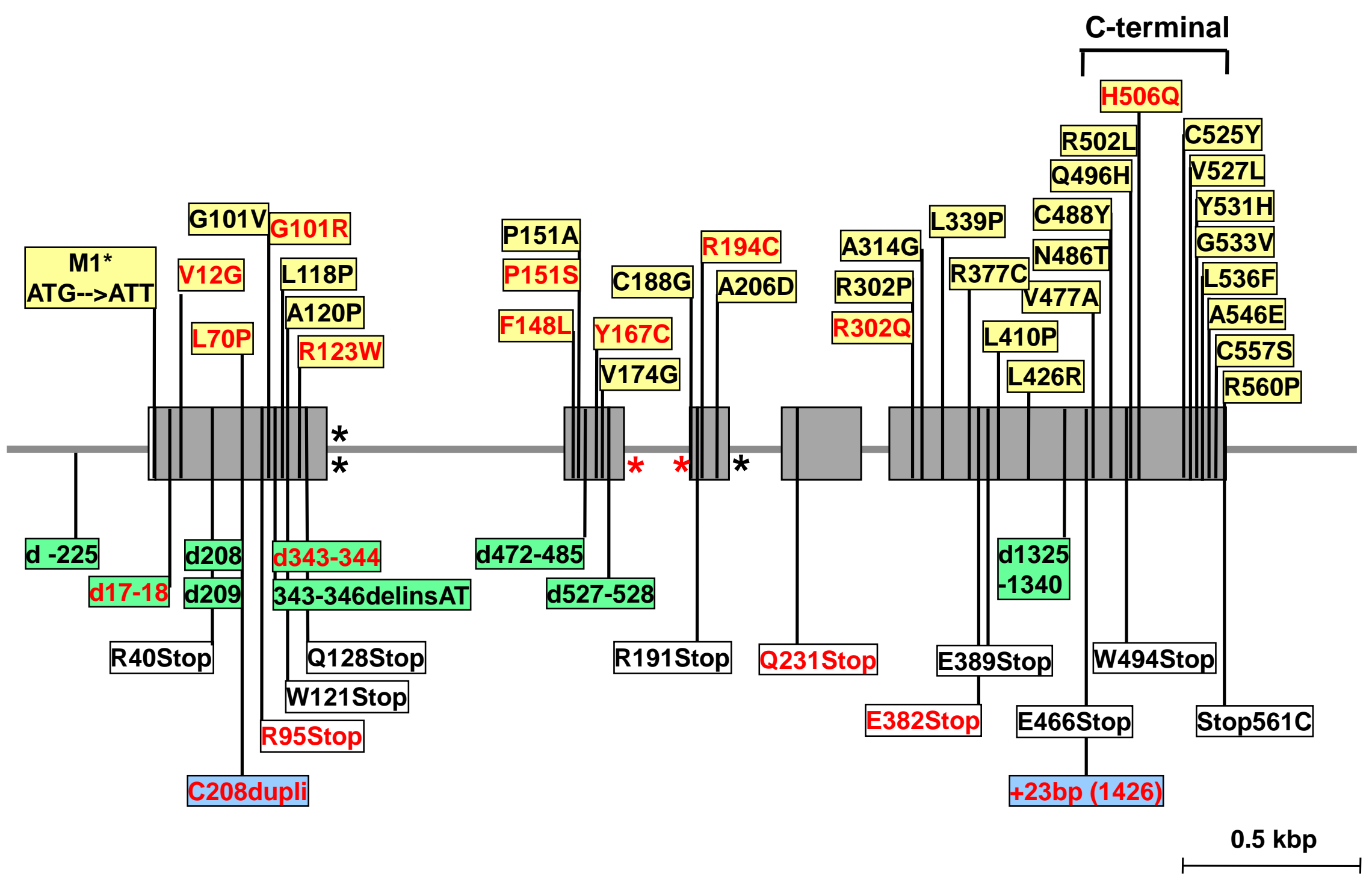

Suppl Fig. 1 


\begin{tabular}{|c|c|c|c|c|c|}
\hline Age & $\mathbf{n}$ & $\begin{array}{c}\text { Genitalia } \\
\text { development } \\
\text { stages }\end{array}$ & Mean \pm SD & Median & $\begin{array}{c}3^{\text {rd }}-97^{\text {th }} \\
\text { percentile }\end{array}$ \\
\hline $0-14$ days & 39 & & $621 \pm 271$ & 584 & $253-1038$ \\
\hline 15 days to 6 months & 26 & & $761 \pm 357$ & 697 & $421-1470$ \\
\hline 6-21 months & 26 & & $1253 \pm 502$ & 1132 & $684-2329$ \\
\hline 2 to 8.9 years & 95 & & $782 \pm 461$ & 684 & $236-1831$ \\
\hline \multirow[t]{5}{*}{$9-18$ years } & 34 & G1 & $741 \pm 327$ & 713 & $257-1371$ \\
\hline & 34 & $\mathrm{G} 2$ & $419 \pm 301$ & 295 & $69-1017$ \\
\hline & 42 & G3 & $121 \pm 114$ & 71 & $30-423$ \\
\hline & 41 & G4 & $75 \pm 40$ & 65 & $33-164$ \\
\hline & 60 & G5 & $92 \pm 50$ & 82 & $38-195$ \\
\hline$>18$ years & 24 & & $62 \pm 35$ & 56 & $25-137$ \\
\hline
\end{tabular}




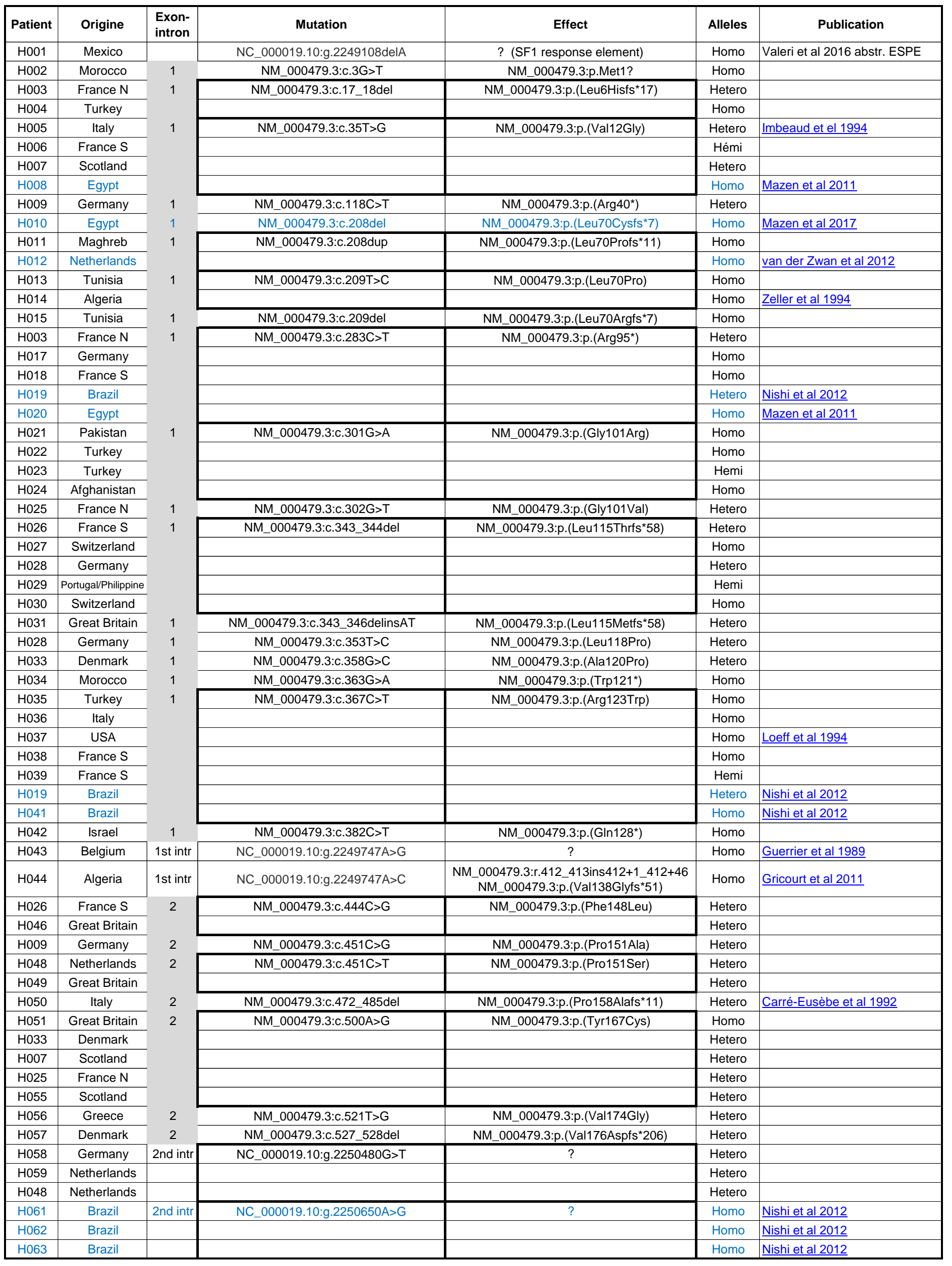




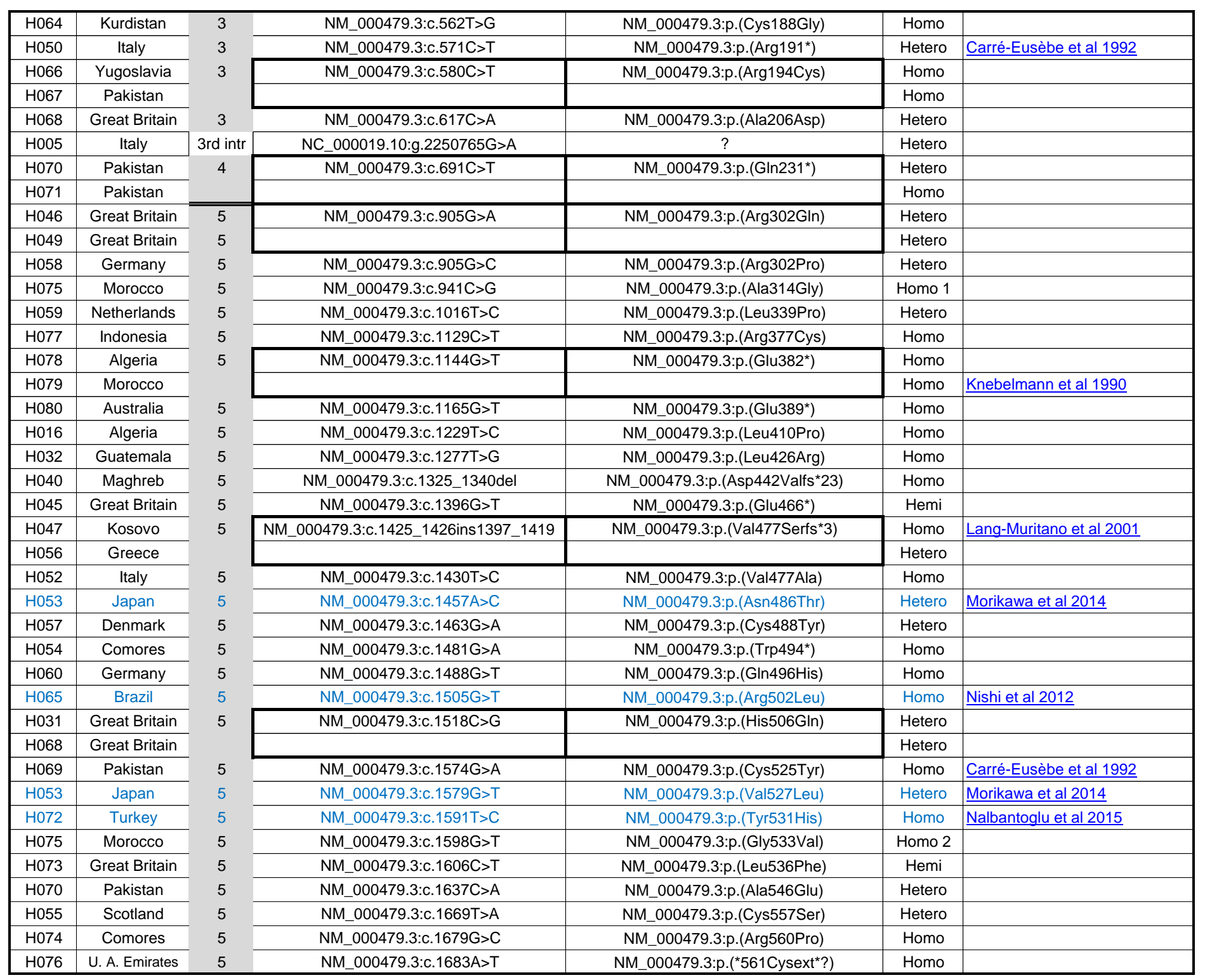




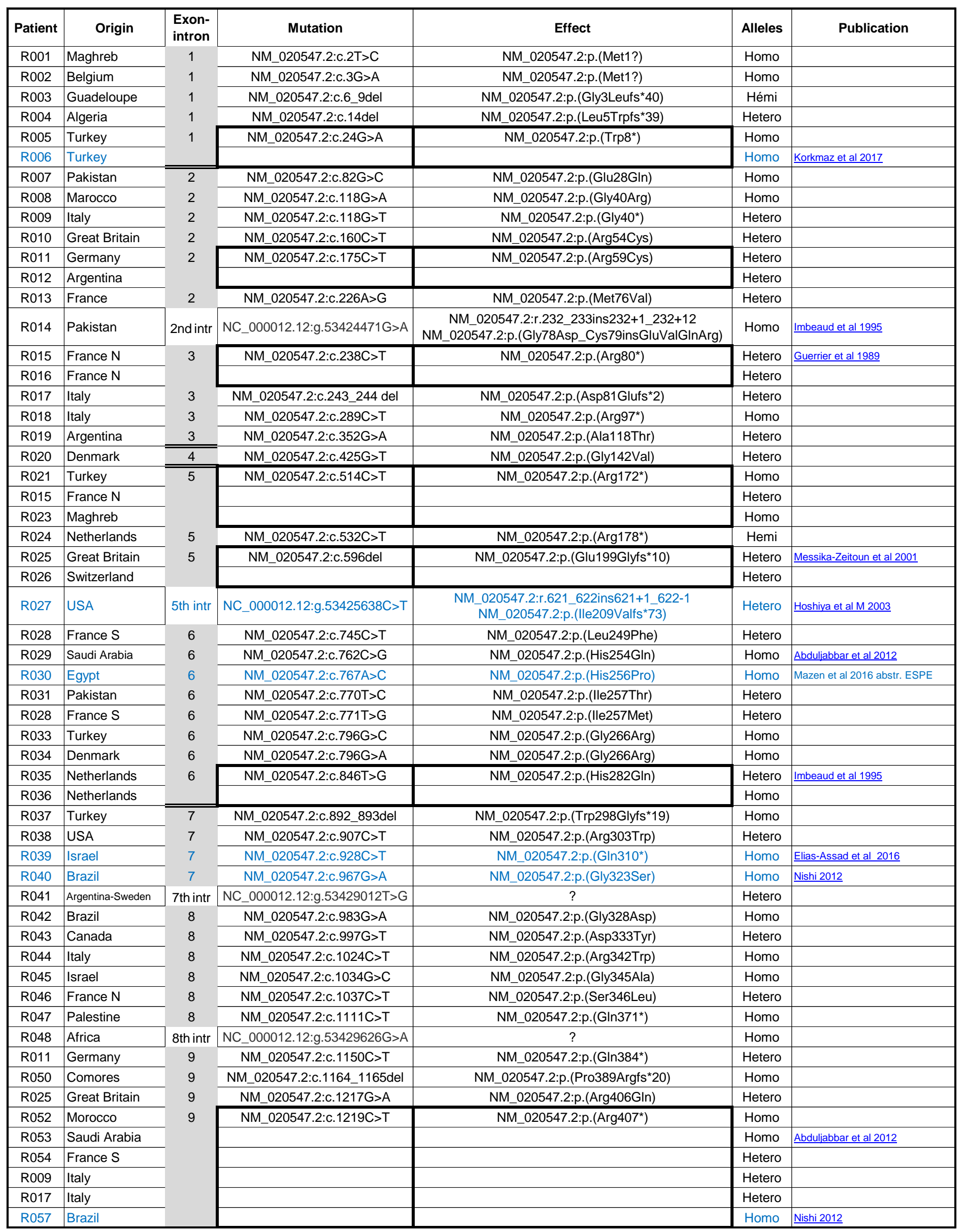




\begin{tabular}{|c|c|c|c|c|c|c|}
\hline R058 & Denmark & 9 & NM_020547.2:c.1225G>T & NM_020547.2:p.(Asp409Tyr) & Homo & \\
\hline R059 & Spain & 9 & NM_020547.2:c.1267C>T & NM_020547.2:p.(Arg423Cys) & Hetero & \\
\hline R060 & Pakistan & 9 & NM_020547.2:c.1277A>G & NM_020547.2:p.(Asp426Gly) & Homo & \\
\hline R061 & Iran & \multirow{21}{*}{$\begin{array}{l}10 \\
10\end{array}$} & NM_020547.2:c.1317_1325del & NM_020547.2:p.(Tyr440_Ala442del) & Homo & \\
\hline R063 & Sweden & & & & Homo & \\
\hline R054 & France S & & & & Hetero & \\
\hline R065 & France S & & & & Hémi & \\
\hline R068 & France $\mathrm{N}$ & & & & Homo & \\
\hline R069 & Germany & & & & Homo & \\
\hline R019 & Argentina & & & & Hetero & \\
\hline R071 & Russia & & & & Hemi & \\
\hline R013 & France & & & & Hetero & \\
\hline R026 & Switzerland & & & & Hetero & \\
\hline R032 & France N & & & & Hetero & \\
\hline R049 & Sweden & & & & Homo & \\
\hline R051 & Reunion & & & & Homo & \\
\hline R046 & France N & & & & Hetero & \\
\hline R059 & Spain & & & & Hetero & \\
\hline R012 & Argentina & & & & Hetero & \\
\hline R055 & Switzerland & & & & Homo & \\
\hline R010 & Great Britain & & & & Hetero & \\
\hline R035 & Netherlands & & & & Hetero & Imbeaud et al 1995 \\
\hline R056 & Netherlands & & & & Homo & \\
\hline R041 & Argentina-Sweden & & & & Hetero & \\
\hline R004 & Algeria & \multirow{3}{*}{$\begin{array}{l}11 \\
11 \\
11\end{array}$} & NM_020547.2:c.1499G>A & NM_020547.2:p.(Cys500Tyr) & Hetero & \\
\hline R038 & USA & & & & Hetero & \\
\hline R072 & France $\mathrm{N}$ & & & & Homo & \\
\hline R031 & Pakistan & \multirow{4}{*}{$\begin{array}{l}11 \\
11\end{array}$} & NM_020547.2:c.1504C>T & NM_020547.2:p.(Gln502*) & Hetero & \\
\hline R074 & Germany & & NM_020547.2:C.1510C>T & NM_020547.2:p.(Arg504Cys) & Hetero & \\
\hline R073 & Turkey & & & & Homo & \\
\hline R070 & Italy & & & & Hetero & Avolio et al 2003 \\
\hline R066 & Netherlands & 11 & NM_020547.2:c.1511G>A & NM_020547.2:p.(Arg504His) & Hetero & \\
\hline
\end{tabular}

